\title{
Chemical Preparation Routes and Lowering the Sintering Temperature of Ceramics
}

\author{
Philippe Colomban \\ MONARIS UMR8233, Sorbonne Université, CNRS, 4 Place Jussieu, 75005 Paris, France; \\ philippe.colomban@sorbonne-universite.fr or philippe.colomban@upmc.fr
}

Received: 5 July 2020; Accepted: 3 August 2020; Published: 18 August 2020

check for updates

\begin{abstract}
Chemically and thermally stable ceramics are required for many applications. Many characteristics (electrochemical stability, high thermomechanical properties, etc.) directly or indirectly imply the use of refractory materials. Many devices require the association of different materials with variable melting/decomposition temperatures, which requires their co-firing at a common temperature, far from being the most efficient for materials prepared by conventional routes (materials having the stability lowest temperature determines the maximal firing temperature). We review here the different strategies that can be implemented to lower the sintering temperature by means of chemical preparation routes of oxides, (oxy)carbides, and (oxy)nitrides: wet chemical and sol-gel process, metal-organic precursors, control of heterogeneity and composition, transient liquid phase at the grain boundaries, microwave sintering, etc. Examples are chosen from fibers and ceramic matrix composites (CMCs), (opto-)ferroelectric, electrolytes and electrode materials for energy storage and production devices (beta alumina, ferrites, zirconia, ceria, zirconates, phosphates, and Na superionic conductor (NASICON)) which have specific requirements due to multivalent composition and non-stoichiometry.
\end{abstract}

Keywords: synthesis; sol-gel; liquid precursors; metal-organic; densification; non-stoichiometry; oxides; carbides; nitrides; electrolytes

\section{Introduction}

Firing at high temperature not only increases the cost of production, but above all it limits the choice of materials that can be sintered together. Consequently, several strategies are implemented to be able to (co-)sinter but also to control both the grain size and the porosity in devices associating several phases. This is particularly necessary for electrochemical devices associating electrodes, current collectors, and electrolyte necessary for the realization of sensors, batteries, fuel cells, electrolyzers, $\mathrm{CO}_{2}$ converters, etc., as well as the preparation of composites with special properties, mechanical or electrical. This is also necessary for composite materials, particularly for those associating (small diameter) fibers in a ceramic matrix. The definition of high-temperature materials is subjective and mainly depends on the methods and the device considered. We choose to consider under this name materials which require sintering at a temperature above $1200{ }^{\circ} \mathrm{C}$ using standard powder and for which the sintering temperature must be lowered to optimize their properties and associate them with other phases in order to make a device. Furthermore, sintering at temperatures above $1250{ }^{\circ} \mathrm{C}$ requires special kilns and resistors.

Unlike the art of glass, which is based on the mastery of homogeneity, ceramic art consists of the mastery of heterogeneity. Therefore, potters and modern ceramists making pottery, bathroom ceramics, porcelain tableware, etc., do not seek to use very pure chemicals available from chemists, but raw materials, natural or at low/moderate prices [1-3]. In addition, many impurities are essential for sintering $[4,5]$. It is the same for many advanced ceramics. The prodigious development of ceramic 
production for almost 12,000 years [6,7] results from the availability of a natural nanometric raw material, clays, and potters have understood that ceramic raw materials must be in fine powder form. For this reason, traditional potters used clays and ultrafine powders obtained by heat treatment of natural rocks and products (chalk, wood/plant ashes, shell, etc.) [3]. Consolidation of a grain assembly, i.e., sintering, requires the welding of adjacent grains [4,5]. For that, they must be firstly in close contact and the atoms move (diffusion, evaporation/condensation, etc.) to widen the contact. The control of the reactivity of a powder does not depend on the average composition but on the local composition in contact with the grains. An $A_{x} B_{y} C_{z} D_{e}$ compound can be obtained in several ways, $A_{x} B_{y}+C_{z} D_{e}$, $A_{x} D_{e}+B_{y}+C_{z}, A_{x / 2}+A_{x / 2} B_{y} C_{z} D_{e}$, etc., and the reaction(s) will rarely be complete. Knowledge of phase diagrams and in particular the temperature required to obtain the 'first' liquid phase is, therefore, essential $[4,5,8]$. One or more phases can be liquid when the others are solid. Volatility and condensation efficiency can also be variable. Sintering is, therefore, a very complex operation, and this is particularly true for non-stoichiometric compounds for which a defined structure guarantees only specific properties [2,9-13].

For a pure compound, there is a direct relationship between the sintering temperature and the melting temperature $\left(\mathrm{T}_{\mathrm{m}}\right)$, which first depends locally on the atomic diffusion coefficients $[4,5]$, affected by the type of element (ion size) and structure of the phase. Empirically, for a "well compacted" assembly of grains of standard size $(3-10 \mu \mathrm{m})$, sintering of a 'pure' oxide composition requires firing at $0.8 \mathrm{~T}_{\mathrm{m}}$ for a few hours. Reducing the grain size to increase the compaction in the green state and optimizing the structure of the powder(s) decrease the dwell time and the sintering temperature up to $\sim 0.6-0.7 \mathrm{~T}_{\mathrm{m}}$ [14]. Traditional potters took advantage of the heterogeneity of the raw materials using a (temporary) liquid phase at relatively low temperature to accelerate densification: by capillarity action, the liquid phase helps to maximize the contact between the adjacent grains, to dissolve convex corrugations and cause precipitation in concave surfaces and necks in between two grains, leading to densification $[4,5,15,16]$. Indeed, we will show that these traditional procedures are the basis of the 'new' procedures developed for the preparation of advanced ceramics: the so-called chemical, liquid, co-precipitation and sol-gel routes imitating the traditional clay route (easy compacting, rheology control, nanometric particles, etc.) [1,2,9-13]. Addition of flux ( $\mathrm{Li} / \mathrm{NaF}, \mathrm{MgF}_{2}, \mathrm{~B}_{2} \mathrm{O}_{3}$, and $\left.\mathrm{PbO}\right)$ generates a transient liquid phase and facilitates compaction, in particular under pressure, etc. [17]. Obviously, these ceramics cannot be made with raw materials but one of the interests in ceramic technology is the use of solid or liquid precursors with limited purity and cost.

We will first address the chemical production of (ultra)fine powders, as well as the optimization of contact area between individual grains (i.e., compaction in the green state), control of reaction at the grain-grain contact (liquid sintering and gradient effects), control and optimization of the structure and properties, in particular for multicomponents and non-stoichiometric compounds as well as multiphase devices (composites, electrochemical systems, etc.). We will try to highlight the advantages and disadvantages of chemical procedures based on liquid precursors, in particular for their potential in 'emerging' synthesis and (advanced) shaping, also by modern additive manufacturing technologies. The scope is too large to cover in detail and we will limit our objective to a rapid historical overview by privileging the initial publications where often many details are given, since the information is often lost in the most recent publications.

\section{Production of Fine Powders}

The development of advanced ceramic technology really began after the World War II, first with the production of 'high-temperature' ceramics for nuclear energy and weapons (uranium and plutonium oxides, and alumina) $[7,9,18]$, radar systems (ferrites and garnets) $[7,19,20]$, aerospace and aeronautic engines (alumina, $\mathrm{C}$ and $\mathrm{SiC}$ ) [7,21-23], the production of refractory bricks (zirconia, chromite, alumina and beta-alumina) for the steel and glass industry [24], spark plug insulators for automotive engines (porcelain and alumina) $[7,25]$, and the materials for electronics (alumina, perovskites, and ferrites) [7,26-28]. Applications for medical prostheses and health (alumina, zirconia [7,29-31], 
$\mathrm{Si}_{3} \mathrm{~N}_{4}[32,33]$ and phosphates [29-31,34-37]) as well as electrochemical systems of production, storage and energy conversion then developed [7,38-40].

The availability of fine powders and/or viscous precursors with the required cost and purity was the key point. It is important to remember that ceramic technology and chemistry are different fields and have different criteria for the selection of powders. For ceramists, the key criteria are the final properties, reliability and repeatability of the characteristics of the final product and cost of production, which includes the sintering step. It is important to avoid any final machining. If certain impurities can be harmful for certain properties, they must be identified, but many impurities are favorable and generally necessary to achieve high densification.

\subsection{Physical Techniques}

Standard methods for powder production are mechanical, using a roller crusher, roller mill or ball mill. The corresponding average grain sizes are typically close to $\mathrm{mm}$, or ten to a few $\mu \mathrm{m}$, respectively $[15,16,41,42]$. The grinding is necessarily associated with pollution by the wear of the grinding agents (quartz pebbles, metal balls, and zirconia beads/balls). The importance of this stage as attrition was (re-)discovered in the period 1980-1990s [43-53], with the availability of new devices due to the improved reactivity of the powder intense and extended to mixtures of metal oxides and pure metal powders [49]. Measuring the weight loss of the balls or a chemical treatment of the powder makes it possible to compensate or eliminate-in part-this pollution [16]. The grinding is carried out in the liquid phase and the ceramists try to maximize the phenomenon of attrition in order to obtain a (sub)micron powder free of aggregates with 'good' capacity of compacting and sintering-and the appropriate phase. It is also worth noting that reactions, phase transitions and amorphization can be observed during the grinding step [48,54]. Unfortunately, the distribution of the grain size can be important, often not monotonous with aggregates. Sifting or sedimentation separates the powder from the aggregates and larger grains.

\subsection{Chemical Routes}

Very early on, attempts were made to bypass the grinding —and pollution—stage, especially for materials for which the high cost of the raw materials was not critical. For instance, the glass window-covering layer and the preparation of advanced glass pieces date from the first half of the 20th century: a patent on a coated film made from organic precursors was filed in 1939 [55]. Research activities on the preparation of 'gel' for producing optical glass but also powder of silicate compositions began in the 1960s and many review papers were published in the 1980s [55-67]. Soda silicate, a viscous liquid, was traditionally used for bonding and restoration of old pottery. In fact, the book of Iller [68] about the chemistry of silica and the book of Bradley, Mehrotra and Gaur [62] concerning the preparation of metal-organic precursors make the scientific context available. Important complements regarding the preparation of alkoxides suitable for ceramics have been reported by Okamura and Bowen [63]. Emphasis was placed on the preparation of oxides from alkoxides, and the first book on the subject was edited by Klein [11].

In fact, until the end of the 1960s, the chemically prepared compositions were very simple, such as $\mathrm{UO}_{2}, \mathrm{Al}_{2} \mathrm{O}_{3}$ and $\mathrm{ZrO}_{2}[9,12,18,29,56-59]$. The potential of using liquid metal-organic precursors to prepare advanced ceramics with a complex non-stoichiometric composition was demonstrated for the first time more than ten years later by the Sandia Labs (Albuquerque) for the production of fully transparent PLZT ceramic (Pb-La zirconate-titanate). PLZT wafers were necessary to produce Kerr cells for the glasses of strategic US air force pilots [7,27,64]. Almost simultaneously, the same research was carried out in France at the Thomson-CSF (now Thales R\&D) for French air force pilots $[2,65]$. Perfect homogeneity of the $\mathrm{Zr} / \mathrm{Ti}$ ratio at each point of the wafer and a precise composition $\left(\mathrm{Pb}_{1-\mathrm{x}} \mathrm{La}_{\mathrm{x}}\left(\mathrm{Zr}_{0.65} \mathrm{Ti}_{0.35}\right)_{1-\mathrm{x} / 4} \mathrm{O}_{3}, \mathrm{x}=0.09\right)$ were necessary to obtain the required opto-ferroelectric properties. Achieving $99.8 \%$ densification-and associated transparency—required a hot-pressing technique when ceramic powder was conventional, but the homogeneity of the $\mathrm{Zr} / \mathrm{Ti}$ ratio was not obtained at 
the required scale [66]. The hot-pressing cycle must completely remove the excess $\mathrm{PbO}$ added as a (liquid) sintering agent in order to avoid red coloring. The $\mathrm{Zr}$ - and Ti-alkoxide mixture in propanol (these chemicals were of high quality and available at low prices because they were widely used as intermediates in the Ziegler-Natta reaction and for the production of alcohols) guaranteed homogeneity at the molecular scale $[64,65]$ and allowed sintering to transparency without hot pressing, a less expensive and more productive technique. Furthermore, the solution of lead acetate formed by the hydrolysis of alkoxides was used to dissolve powders of lanthanum and lead oxides [65]. Thus, the main drawback of "chemical" synthesis (besides the enormous volume of liquid to be handled) was limited, the Zr- and Ti-based chemicals being not too expensive.

It should be noted that the formulation used to qualify such a synthesis was variable-chemical preparation, co-precipitation, colloidal, etc. [60,67]. Up to the 1980s, the term 'sol-gel' was not widelly used, although sols, gels, or xerogels were in fact prepared [68]. The term 'co-precipitation' was largely used. It is important to note that the process can directly give a gel or a sol (which can again form a gel by removing most of the liquid or modifying the interactions between particles; some liquid remains in the pore network). These methods are extensions of the uses of the colloidal suspension of silica Ludox $^{\circledR}$ (now available from GRACE) or of traditional sodium silicate 'solution'. Alkali activation of silicate (as well of aluminosilicates, etc.) raw materials has great potential for cold consolidation of ceramic suspensions and, under the name of 'geopolymers', their use has been explored [69-72]. Geopolymers are aluminosilicate binders which harden at low temperature $\left(25-80{ }^{\circ} \mathrm{C}\right)$ in a relatively short amount of time ( 2 to $48 \mathrm{~h}$ ). They are typically made by mixing an aluminosilicate source such as metakaolin or fly ash into alkaline silicate solution and curing in a sealed environment. The products of cold consolidation may be particularly stable by themselves (in case of formation of 'zeolitic' gels), but the firing treatments lead to a variety of other interesting ceramics. The necessary processing details required to fabricate high-strength, well-reacted geopolymers have been established [73] but the main use is to prepare concrete [74].

The sol-gel transition is only possible in certain cases, as observed with the traditional clay-based route [1]. Studies on sols and colloids, in particular those giving 'nice' particles and crystals (called colloids) with well-defined shapes, received great attention in the 1980s [75] and form the basis of the preparation of ordered nanometric assemblies currently in the spotlight [76,77].

According to Segal $[9,78]$, the chemical syntheses are coprecipitation, molten salts, sol-gel processes, hydrothermal techniques, reactions in the liquid phase and the gas phase, pyrolysis of polymer, gel based on a Pechini resin method [79] and citrates, aerosols and emulsions. Figure 1 summarizes the different routes.

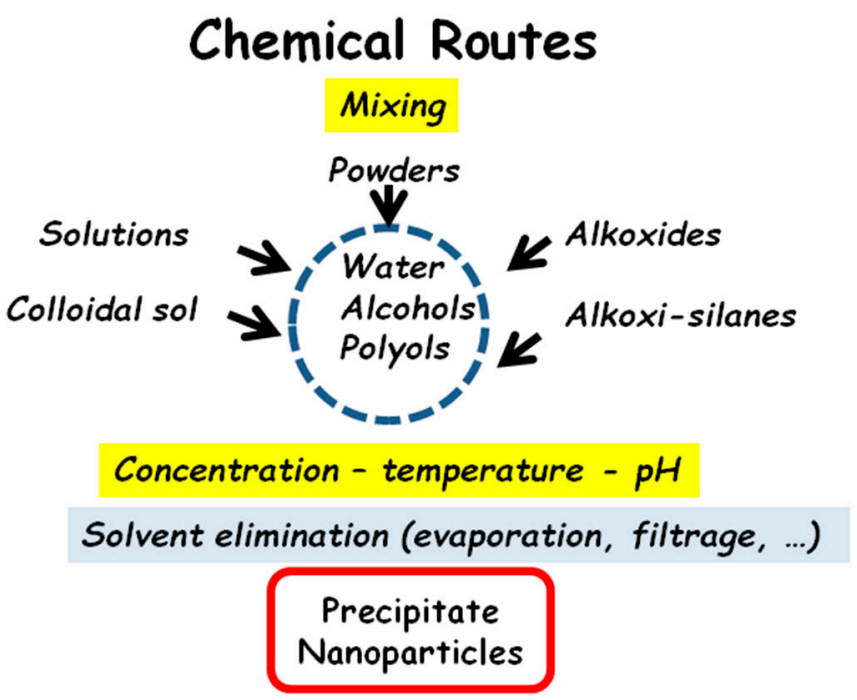

Figure 1. Schema of the different chemical routes. 


\subsubsection{Oxides}

The 'solvents', or more precisely the liquid media used, are water, alcohols, thiols and polyols $[1,9,12,13,56,65,68,80]$. There are a variety of salts that can be dissolved in these solvents such as nitrates, chlorides, acetates, etc. The anions of salts selected must be easily eliminated during the chemical process or by heating. The most widely used metal-organic chemicals for preparing oxides are alkoxides $\left(\mathrm{M}(\mathrm{OR})_{\mathrm{n}}\right)[1,63,81-84]$. Mixed alkoxides such as ${ }_{\mathrm{n}}(\mathrm{RO}) \mathrm{M}-\mathrm{O}-\mathrm{M}^{\prime}(\mathrm{OR})_{\mathrm{p}}$ or more complex formulations can be synthesized to improve homogeneity and facilitate the control of hydrolysis/condensation reactions but their properties are not a linear combination of the pure components [82].

One of the main characteristics of alkoxides is their easy hydrolysis (sometimes too fast (instant!) or too slow)

$$
\mathrm{M}(\mathrm{OR})_{n}+n \mathrm{H}_{2} \mathrm{O}=>\mathrm{M}(\mathrm{OH}) n+n \mathrm{ROH}
$$

and, simultaneously, polycondensation (in other words, polymerization).

$$
\mathrm{M}(\mathrm{OH})_{n}=>n / 2 \mathrm{H}_{2} \mathrm{O}+n \mathrm{MO}_{n / 2}
$$

After drying, the resulting gel has a complex composition such as

$$
\mathrm{MO}_{n-x-\varepsilon}(\mathrm{OH})_{2 x}(\mathrm{O}-\mathrm{R})_{\varepsilon} m \mathrm{H}_{2} \mathrm{O} n \mathrm{ROH}(x \sim 0.1, \varepsilon \sim 0,0<m<0.2, n<0.1)
$$

and is generally called xerogel or 'glass' [1,80-86]. The substitution of certain $\mathrm{R}$ branches by other organic chains which do not react with water but can polymerize (vinyl, ... ), couple with a substrate $($ epoxy, ... ) or have hydrophobic properties gives rise to another class of materials, so-called hybrid materials for specific properties [1], but this is out of the scope of this review. The thermal treatment(s) of these hybrid materials, if any, is carried out at low temperatures $\left(<400^{\circ} \mathrm{C}\right)$ and, therefore, they remain (very) porous although they can be rather hard and transparent. The specific surface of a transparent xerogel can reach $1000 \mathrm{~m}^{2} / \mathrm{g}$, much larger than for standard fine powders, and the gels exhibiting the highest surface are called aerogel $[1,87-93]$. The hydrolysis reaction hardly depends on the metal type. The state of the alkoxide at room temperature, liquid or solid, depends on the length of the $R_{n}$ chain. For certain alkoxides (Al, Ge, etc.), handling in a glove box without water traces is required; it should be without oxygen traces for certain transition metal alkoxides $[82,85,86,88]$. For some others $(\mathrm{Si}, \mathrm{Zr}, \mathrm{Ti}, \mathrm{Al}-\mathrm{O}-\mathrm{Si})$, handling is possible under standard conditions after dilution in (water-free) 2-propanol [65,82,94,95].

A good example of the importance of the alkoxide selection is the preparation of aluminosilicates. Aluminum sec-butoxide is very hygroscopic and must be handled in a glove box free of water traces to avoid instant hydrolysis and uncontrolled precipitation and heterogeneity. On the contrary, the hydrolysis of silicon ethoxide is slow and depends on the $\mathrm{pH}$. The alkoxide $(\mathrm{BuO})_{2}$-Al-O-Si- $(\mathrm{OEt})_{3}$ has an intermediate behavior and can be handled in ambient air $[86,94,95]$ and hydrolyzed under control. Transition metal and lanthanide/actinide alkoxides have very specific properties and are difficult to use in the sol-gel routes.

The main characteristics and advantages of these routes are that (a part of) elements are mixed in the liquid state — thus giving homogeneity at the molecular level—and 'the solid phase formation' (in fact a gel is not a solid but a viscous/plastic phase) leads to colloids or phases of similar size, generally at the submicron level $[1,2,14,83,84]$. The polymerization of gel formers $(\mathrm{Si}, \mathrm{P}, \mathrm{Al}, \mathrm{Zi}$, $\mathrm{Ge}$, etc. $[1,82])$ leads to the formation of an entity, up to a size which can exceed a micrometer, that can be dispersed in a liquid (sol) or perfectly assembled to form a transparent but microporous (shaped) 'solid' [1,14,96-99]. The best technique for preparing an optically clear gel/xerogel is slow hydrolysis/polymerization [1,96-99] but pressure sintering is also effective $[1,14,100]$. In some cases, the optical clarity is preserved after heat treatment, in particular for glassy compositions [81], and this property was demonstrated to obtain colored glasses [101]. 
The reactivity - and the sintering - strongly depend on the reaction surface. Heat treatment under $\mathrm{NH}_{3}, \mathrm{H}_{2}, \mathrm{CO}$, etc., can change the composition to (oxy)nitrides, (oxy)carbides, etc. [1]. An assembly of nanograins can sinter easily if the contact zone between the adjacent grains is high-in other words, if the compaction in the green state (i.e., before the heating) is already high.

Chemical elements can be classified into two groups:

(i) The elements which establish covalent bonds, called gel or glass former (Si, P, Ge, Al, etc.) [1], form 'molecular' moieties-in other words, 'polymerize'.

(ii) The elements which remain as 'isolated' ions; they can remain dissolved in the 'solvent' and/or adsorbed on the surface, external surface of the artefact and internal surface of the pores of the 'precipitate'; for instance, $\mathrm{Na}^{+}, \mathrm{K}^{+}, \mathrm{Li}^{+}, \mathrm{Ca}^{2+}$, etc.

Table 1 lists examples of the compositions prepared with liquid metal-organic precursors. The main problem is the difficulty of obtaining the exact 'target' stoichiometry due to the loss of the ions/elements present in the liquid 'solvent'. Ions can be partially lost when the 'solvent' is removed. Different strategies can be used.

Table 1. Examples of compositions prepared with liquid metal-organic precursors $[2,14,17,32,57,59,64,65,68,72,73,81,96-136]$.

\begin{tabular}{|c|c|c|}
\hline Composition & Reagents & References \\
\hline Silica & $\begin{array}{l}\text { Ludox }^{\circledR} \\
\text { Alkoxides }\end{array}$ & $\begin{array}{c}\text { Iller [68], Roy [102] } \\
\text { Phalippou et al. [81] } \\
\text { Dunn \& Zink [101] }\end{array}$ \\
\hline Alumina & Alkoxide & Colomban [96] \\
\hline $\begin{array}{l}\text { Aluminates ( } \beta \text { alumina) } \\
\text { Ytrium aluminate }\end{array}$ & $\begin{array}{l}\text { Alkoxide }+\mathrm{Na} / \mathrm{K} \text { ions } \\
\text { PVA/EG routes }\end{array}$ & $\begin{array}{l}\text { Colomban [100,103-105] } \\
\text { Gülgun et al. [125] }\end{array}$ \\
\hline $\begin{array}{l}\text { Aluminosilicates } \\
\text { Cordierite } \\
\text { Leucite }\end{array}$ & $\begin{array}{l}\text { Alkoxide mixture or } \\
\text { Al-O-Si alkoxide } \\
\text { Pechini resin/PVA } \\
\text { "Geopolymers" }\end{array}$ & $\begin{array}{c}\text { Yoldas [57] } \\
\text { Colomban [97] } \\
\text { Lee and Kriven [126] } \\
\text { Bell et al. }[72,73]\end{array}$ \\
\hline $\mathrm{Na} / \mathrm{Li}$ aluminosilicates & $\begin{array}{c}\text { See above }+ \\
\mathrm{Na} / \mathrm{Li} / \mathrm{K} / \mathrm{Ba} / \mathrm{Ca} \text { ions }\end{array}$ & $\begin{array}{c}\text { Perthuis et al. [17,106], } \\
\text { Bruneton et al. [107] } \\
\text { Colomban and Lapous [108] }\end{array}$ \\
\hline Zirconia/Ceria & Alkoxide & $\begin{array}{l}\text { Mazdiyasni [59] } \\
\text { Bruneton and Colomban [98] } \\
\text { Kosacki et al. (2002) [131,132] }\end{array}$ \\
\hline $\begin{array}{c}\text { Zirconates/Titanates } \\
\mathrm{BaTiO}_{3}\end{array}$ & $\begin{array}{l}\text { Alkoxides + ions } \\
\text { Ethylene glycol (EG) }\end{array}$ & $\begin{array}{c}\text { Snow [64], Colomban [2,65], } \\
\text { Nagata et al. [109] } \\
\text { Lee et al. [127] }\end{array}$ \\
\hline $\begin{array}{c}\text { NASICON } \\
\mathrm{Na} / \mathrm{Li} \text { zircon-phospho-silicates }\end{array}$ & Alkoxides + ions & $\begin{array}{l}\text { Perthuis and Colomban [99] } \\
\text { Bouquin et al. [14] }\end{array}$ \\
\hline $\begin{array}{l}\text { Composites reinforced with } \\
\text { nanoparticles, fibers, textiles }\end{array}$ & Alkoxides + salts & $\begin{array}{c}\text { Vendange and Colomban [110], } \\
\text { Vendange et al. [111] } \\
\text { Mouchon and Colomban [112], } \\
\text { Karlin and Colomban [113], } \\
\text { Colomban and Wey [114] }\end{array}$ \\
\hline
\end{tabular}


Table 1. Cont.

\begin{tabular}{|c|c|c|}
\hline Composition & Reagents & References \\
\hline Silicon carbides * & $\begin{array}{c}\text { Silanes } \\
\text { Polycarbosilanes }\end{array}$ & $\begin{array}{c}\text { McDiarmid [115], } \\
\text { Corriu [124] } \\
\text { Tanaka and Kurachi [116], } \\
\text { Okamura et al. [117] } \\
\text { Colomban [118] } \\
\text { Hasegawa et al. [128] } \\
\text { Burns et al. [129] } \\
\text { Naslain [133] } \\
\text { Bayya et al. [130] } \\
\text { Shin and Tanaka [136], }\end{array}$ \\
\hline $\begin{array}{c}\text { Silicon nitrides * } \\
\text { Oxides } \\
\text { from polymer precursors } \\
\text { (zircon, mullite, zirconia, etc.) }\end{array}$ & $\begin{array}{l}\text { Polysilazanes } \\
\text { Polyorganoboro- } \\
\text { Silazanes, etc. } \\
\text { Polysilsequioxanes }\end{array}$ & $\begin{array}{c}\text { Durham et al. [119], } \\
\text { Kroke et al. [120], } \\
\text { Bill and Aldinger [32], } \\
\text { Riedel et al. [33], Cooke [121], } \\
\text { Bill et al. [122], } \\
\text { Onbattuvelli and Atre [123] } \\
\text { Parcianello et al. [135] } \\
\text { Parcianello et al. [134] }\end{array}$ \\
\hline
\end{tabular}

${ }^{*}$ Actually complex Si-C-B-N(-O) compositions are possible.

First, the excess of these elements/ions is adjusted. Generally, ions diffuse quickly and contribute to the sintering process by forming a transient liquid phase at the grain boundary $[4,5,15,16]$. The final surplus (depending on the pristine excess) is, therefore, linked to the sintering cycle (temperature, duration, etc.) - and to the volume of the prepared batch. Contrary to the common thought of chemists, the use of water as a solvent whatever the carbonation potential of ions such as $\mathrm{Ca}^{2+}, \mathrm{Ba}^{2+}, \mathrm{Sr}^{2+}$, etc., by reaction with $\mathrm{CO}_{2}$ dissolved in the water is more effective than handling in alcohol without water or in a glove box. A limited amount of carbonate at the grain boundary promotes the sintering. Control of the final object after (co-)sintering is the only relevant criterion and step-by-step optimizations rarely lead to an optimal result.

Second, the design of a hybrid route in which some elements can be dissolved in the liquid mixture, after they have been incorporated in the form of powder $[1,2,65]$, limits the cost of preparation.

\subsubsection{Carbides, Nitrides, etc.}

The preparation strategies for silicon and aluminum carbides, nitrides (and oxycarbides, oxynitrides) are somewhat different. Unlike the alkoxide/chemical routes, where the route has two stages, like the traditional clay route (forming in the green state, and then firing), the preparation of carbides and nitrides depends on viscosity control. For the alkoxide routes to the oxide compositions, the material to be removed consists of water (and proton). The routes to carbides and nitrides require $3 \mathrm{D}$ reticulation and precise elimination of excess $\mathrm{C}$ and $\mathrm{N}$, as well as control of the oxygen content. However, this liquid precursors-based route provides a means for the synthesis of new materials (fibers, composites), thanks to viscosity control, which cannot be easily obtained at a low temperature by conventional methods [133]. The manufacture of dense bulk ceramics in the Si/Al/X/C/N systems $(\mathrm{X}=\mathrm{B}, \mathrm{Zr}, \mathrm{Ti}, \mathrm{O}$, etc.) is achieved by crosslinking of the polymeric ceramic precursor followed by a step of polymer transformation into ceramic (ceramization). The crosslinked precursor can be milled, mixed with powder, compacted and pyrolyzed to form dense, amorphous silicon carbonitride monoliths or polycrystalline composites which withstand oxidation in air at $1600{ }^{\circ} \mathrm{C}$ (additives are generally added to improve the sintering and limit the grain growth). $\mathrm{M}-\mathrm{O}$ bonds and oxide precipitates are used to control grain growth and thermal stability. An excess of carbon is common and it is an important challenge to minimize the content. Chemical vapor deposition (CVD) methods using volatile precursors can also be used [133]. The spinning of fiber combined with thermal treatments leads to 
dense ceramic fibers. On the contrary, infiltration of preforms, even in autoclaves, leads to rather porous objects [133].

These procedures allow the preparation of silicon-based ceramics in the system SiCNO. Common preceramic polymers are poly(organosilazanes), poly(organosilicarbodiimides) and poly (organosiloxanes) (Table 1). These materials generally exhibit enhanced thermomechanical properties, i.e., temperature stabilities up to approximately $1500{ }^{\circ} \mathrm{C}$. Recent research has shown that, in some cases, the high temperature stability in terms of decomposition and/or crystallization can be increased even up to $2000{ }^{\circ} \mathrm{C}$ if the pre-ceramic polymer contains some amount of boron. The composition and microstructure are a result of the molecular structure of the pre-ceramic polymer. Consequently, the differences observed in the macroscopic properties are also closely related to the variation in composition and solid-state structure of the precursors. Fundamental correlations between the composition and structure of the pre-ceramic compounds and the architecture of the amorphous state are revealed by light/X-ray, Raman and neutron scattering [83,84,113,122,133,137-139].

An important advantage of all chemical routes is the possibility of obtaining ceramics with nanometric grains after intermediate amorphous, but dense state. The amorphous state guarantees great homogeneity but the density of bonds per unit of volume is lower than that of crystalline counterpart. Therefore, the intermediate state between the glassy and crystalline state is a good compromise and has been sought for ceramic fibers [83,84,118,137-139].

The unique combination of thermal and mechanical properties exhibited by (oxy)carbides and (oxy)nitrides has proven itself in the applications of the electronics, automotive, defense and aerospace industries $[32,33,118,123,133]$. The successful conversion of their properties to end applications lies in the manufacture of these ceramics into fully dense microstructures. Efforts have been made by researchers to date in the development of near-net-shape fabrication processes $[7,23,36,37,114]$ which can produce ceramic components of complex-shaped (e.g., compressor wheel) parts with or without minimum machining and no microstructural defects (plasma-assisted compaction, injection molding, pyrolysis of pre-ceramic polymers, etc.).

\section{Optimization of the Grain-Grain Contact}

\subsection{Compaction and (Viscous) Liquid Routes}

Optimal compaction of the grains before heat treatment is the key point to promote densification. For the clay-based composition, the green density is obtained by the control of the water content associated with the clay particles. The water lubricates the sliding of the clay layer under the stress imposed by the potter (shaping by hand) or the plug (mechanical shaping). For the slurry process, the absorption of water by the plaster mold provokes the compaction of the deposit formed on the surface of the plaster mold, etc. $[15,16,140]$. The transformation of the suspension into a green body in colloidal forming depends mainly on the characteristics of suspension on one hand, and the absorbent substrate on the other-drying and solidification are the key links. In the absence of water to lubricate the motion and arrangement of grains by pressing, high hydrostatic/isostatic pressure is applied and plasticizers are added [141-144]. Cold isostatic compaction, where a shaped rubber bag is filled with powder, sealed and then subjected to high overall pressure to produce a compacted green component, is a common processing route for ceramic parts [143,144]. Isostatic (i.e., hydrostatic) pressing gives a better compaction than the plug/mold set (simple or double action): the pressure applied to an assembly of hard grains leads to a grain-grain load transfer and hence a decrease in the effectiveness in contact from grain to grain. The key to isostatic pressing is the design of the rubber bag, which is in general both different in size and shape from the green body and preparation of the powder (shape, additives). It is important to limit machining of the green compact. Spherical nanoparticles with narrow size distribution are crucial to obtain a homogeneous density and a low pore-particle size ratio in green compacts, and then to preserve the grain size at full densification. 
One of the advantages of the sol-gel/alkoxide route is that the gel contains water. Like clay, the residual water helps to lubricate the rearrangement of the grains as well as their deformation ("sintering") in the green state under pressure at room temperature, sometimes up to optical clarity, or at least translucency-properties characteristic of a nearly full densification [1,2,14]. In comparison, the complete compaction of hard spheres does not lead to more than $60 \%$ densification. Slow hydrolysis of alkoxide in solvent (e.g., hexane) and sedimentation also leads to optically clear pieces [1,96-99].

\subsection{Additives}

When water cannot act as a lubricant to promote grain rearrangement and transfer of load/pressure from grain to grain (the presence of liquid leads to pressure transfer, much more effective than the load), a few \% or less organic lubricants such as polyvinyl alcohol (PVA), polyethylene glycol (PEG), polyacrylic acid (PAA), camphor, stearic acid and glycerine are added $[145,146]$. Sol-gel routes generally allow avoiding the use of these organic binders. Adding camphor, a volatile organic compound, can help compact the ultrafine powder. The coating of (hard) grains with gel promotes compaction under pressure in the green state [147] and allows the preparation of functionally and hierarchical graded composites $[2,83,84,148]$.

\subsection{Anisotropy Control}

The geometrical arrangement/packing of a grain population depends not only on the size but also the shape and size distribution of the grains. The anisotropic shape (platelets, needles/whiskers, etc.) is very harmful and special strategies are necessary to improve the green density [147-152].

\section{Grain-Grain Reaction and Densification}

Various strategies have been adopted to approach the complete densification, including pressure-less sintering controlled by the atmosphere (vacuum, $\mathrm{O}_{2}, \mathrm{H}_{2}, \mathrm{PbO}$ or $\mathrm{Na}_{2} \mathrm{O}$ vapor by immersing the piece in a powder with similar composition, etc.), hot pressing, hot isostatic pressing, microwave sintering, sinter forging and spark plasma sintering. The complete densification of colorless ceramics gives rise to transparency [64-66,153-157]. High pressure is applied to aid densification of nanoparticle rearrangement and sliding, as well as plastic deformation and pore shrinkage. There is much literature available on this subject $[4,5,10,15,16,29-31]$. Low-temperature mass transport strongly activated during the spark plasma sintering of nanoparticles can lead to rapid densification kinetics with limited grain growth if high green density has been previously achieved. However, carbon pollution is frequent and requires complementary oxidizing heat treatment under air or oxygen. It is important to note that diffusion of oxygen atoms in an oxide is very limited below $1200^{\circ} \mathrm{C}$ and, therefore, carbon is well preserved in dense bodies.

\subsection{Liquid-Phase Sintering: Dissolution and Precipitation}

The first mechanism to obtain (complete) densification at a temperature far from the temperature required to melt the assembly of all the grains has been used for millennia to prepare terra cotta, stoneware and porcelain $[1,5,15,157]$. Due to the use of raw materials of different composition and structure, a phase corresponding to the grain A-grain B contact with the lowest liquid phase in the binary diagram $\mathrm{AB}$ in temperature of all the grain-grain configurations will melt first. The liquid phase wets the other grains and the dissolution reaction takes place on the surface of the grains. This is called reaction sintering. As illustrated in Figure 2, the fusion of phase $G$ dissolves the surface of other grains-for example, grains $Q$. Due to the reaction, the composition of the liquid phase varies and, consequently, its melting temperature changes. The progress of the reaction will depend on the temperature $\left(\mathrm{T}_{0}\right)$, duration and size of the grains. This phenomenon is general and can take place at the molecular scale. 

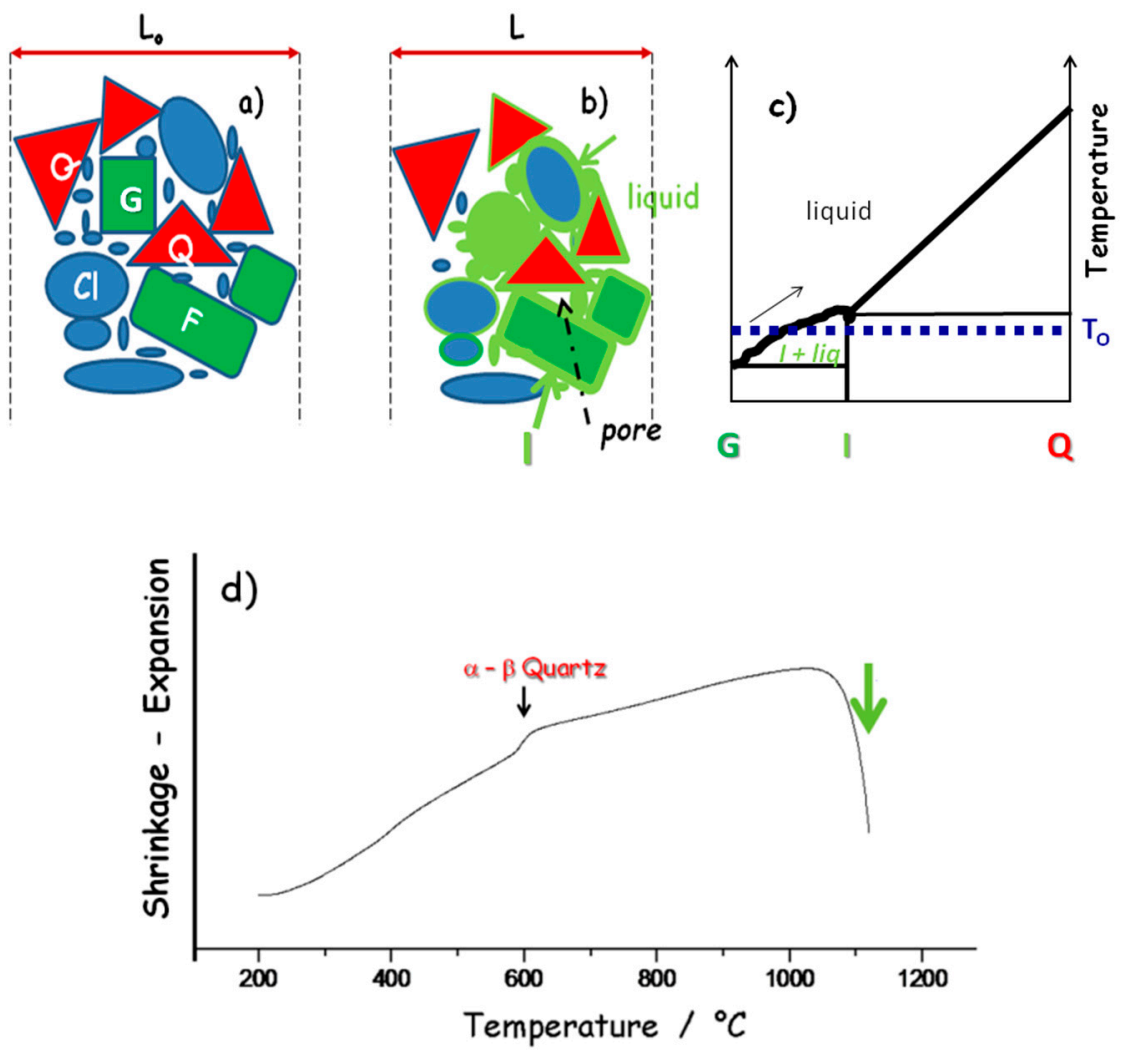

Figure 2. Schematic of liquid-phase sintering of a heterogeneous green ceramic body: (a) compacted grains (green state); (b) reaction sintering, with the molten phases noted in light green; (c) diagram of the $\mathrm{G}-\mathrm{Q}$ phase vs. temperature; (d) plot of the dilatometric behavior during liquid sintering, where the event at $573{ }^{\circ} \mathrm{C}$ corresponds to the $\alpha-\beta$ phase transition of $\mathrm{SiO}_{2}$ quartz grain and the large green arrow indicates the temperature at which a molten phase is formed.

The formation of the molten phase causes a drastic shrinkage which stops when all the liquid phase has been consumed by the reaction and then the thermal expansion begins again $[15,16]$. There is, therefore, an optimal heat treatment. It should be considered that if pressure is applied, the presence of a liquid phase lubricates the rearrangement of the particles and maximizes the homogeneity of the pressure transmission from grain to grain (in the absence of liquid phase, only the loads are transferred and, therefore, the efficiency is geometrically limited).

In fact, for such traditional clay-based ceramics, the volume of liquid phase is large and can reach $30 \%$ of the volume for the porcelain body $[157,158]$. The final material is made of many phases, neo-formed and relics from the raw materials dissolved/reacted to some extent. The volume of liquid phase favored by the sintering aids is much smaller-a few \% or less-and, therefore, being effective requires high packing of grains in the green state in order to maximize the efficiency of the liquid phase. Sintering aids for oxide compositions are primary fluxing agents such as alkali and alkaline earth, boron and bismuth oxides and fluorides [17,106,159-171]. The volatility of a sintering aid is an advantage: complete elimination is possible and single-phase final ceramics can be obtained [17,64,65,106,172-174].

For (oxy)carbides, (oxy)nitrides and boride compounds $\left(\mathrm{SiC}, \mathrm{Si}_{3} \mathrm{~N}_{4}, \mathrm{AlN}\right.$, etc.), sintering optimization requires control of the reactivity of the grain surface/interface by removal or addition of certain phases. For instance, $\mathrm{B}_{2} \mathrm{O}_{3}$ and $\mathrm{ZrO}_{2}$ must be removed and $\mathrm{B}_{4} \mathrm{C}$ must be added for good sintering of $\mathrm{ZrB}_{2}$ [175]. On the contrary, $\mathrm{Al}_{2} \mathrm{O}_{3}, \mathrm{BeO}, \mathrm{Y}_{2} \mathrm{O}_{3}-\mathrm{Al}_{2} \mathrm{O}_{3}, \mathrm{CaO}$ at the grain boundary promotes liquid-phase sintering of $\mathrm{SiC}$ [176-179]. Mastering the phase diagram at the grain surface/interface is thus the key point to optimize sintering. 


\subsection{Deprotonation and Phase Transition}

The densification mechanism of the oxides prepared from alkoxides is different and allows densification without sintering aids. The main characteristic is that oxides produced through chemical routes host large amounts of protons in different forms (water, $\mathrm{OH}^{-}, \mathrm{H}^{+}$), which is generally overlooked. Figure 3 shows the schematic of the structure of a xerogel and its transition to the corresponding oxide as well as the associated thermal shrinkage as a function of the heating temperature [2].
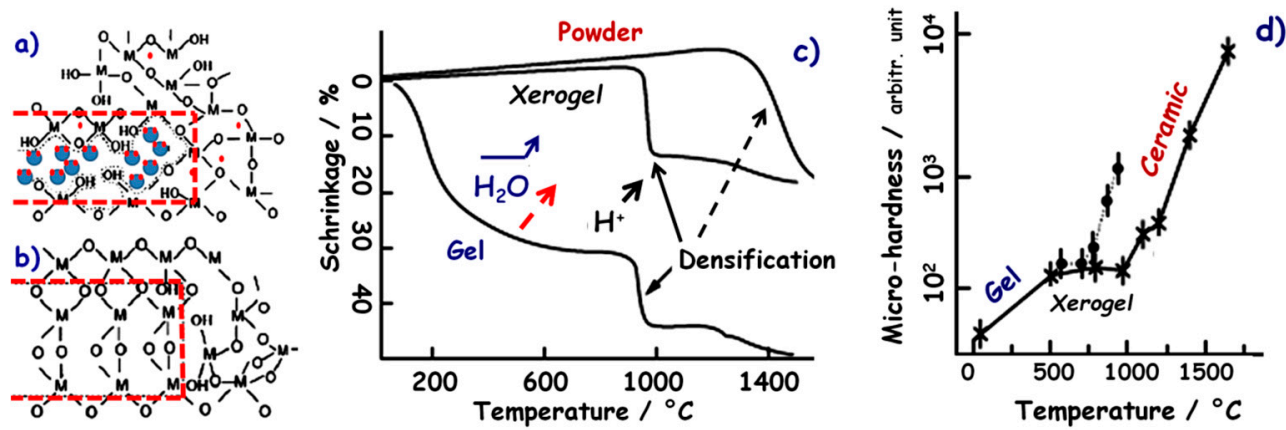

Figure 3. Schema of the transformation of a (micro/meso)porous xerogel (a) into a dense oxide (b); (c) comparison of the shrinkage of a gel, a xerogel and corresponding oxide powder; (d) evolution of the R.T. microhardness (logarithmic scale) with thermal treatment (dashed line: Na superionic conductor (NASICON); solid line: mullite; after [2]).

The hydrolysis/polycondensation reaction forms a polymer network of $\mathrm{M}\left(\mathrm{M}^{\prime}, \ldots\right.$ )-O bonds with a random geometric arrangement which forms 'voids' at the scale of the bond, most of them connected and filled with the liquid medium used for the synthesis (generally water) plus the water created by the reaction (Figure 3a). As a function of the bonding force, the protonic species are eliminated above $120^{\circ} \mathrm{C}$ (surface adsorbed water), $400-500{ }^{\circ} \mathrm{C}$ (hydroxyl groups) and 600 to $1000{ }^{\circ} \mathrm{C}$ (protons). Typically, the pore (equivalent) diameter is between 0.5 and $20 \mathrm{~nm}$ [87,89-91], the pores below $2 \mathrm{~nm}$ being called micropores and those above, mesopores $(2-50 \mathrm{~nm})$. In order to saturate the pending bonds, the surface oxygen atoms are protonated and covered with water [90]. Therefore, the composition of a gel and a xerogel is complex, e.g., $\mathrm{SiO}_{2-x}(\mathrm{OH})_{x} \cdot \mathrm{m} \mathrm{H}_{2} \mathrm{O}$ or $\mathrm{Al}_{2} \mathrm{Si}_{2} \mathrm{O}_{7-\mathrm{x}}(\mathrm{OH})_{\mathrm{x}} \cdot \mathrm{n} \mathrm{H}_{2} \mathrm{O}$ and not $\mathrm{SiO}_{2}$ or $\mathrm{Al}_{2} \mathrm{O}_{3} \cdot 2 \mathrm{SiO}_{2}$, as it is written in most publications.

From the schema, it is obvious that crystallization leads to densification (Figure $3 a, b$ ) and this is confirmed by the thermal expansion/shrinkage measurement for all the products analyzed in the form of pure (silica, alumina, and zirconia) [98] or multi-elemental (aluminosilicates, Na superionic conductor (NASICON), etc.) [91-93,99,107] compositions. The temperature of the crystallization/densification varies from $\sim 500{ }^{\circ} \mathrm{C}$ for zirconia to $\sim 1000{ }^{\circ} \mathrm{C}$ for alumina, aluminosilicates and silicates. Amorphous zirconia [98], alumina [96], aluminosilicates, etc., [97-99] are obtained just before crystallization. Thermogravimetrical analysis (TGA) and spectroscopic studies confirm that the shrinkage jump corresponds to the elimination of "water". The measurement of micro-hardness at room temperature as a function of the maximum heating temperature imposed on the sample (Figure 3c) shows three stages, like the shrinking pattern: a regular increase when excess water is gradually eliminated; a plateau at the state of xerogel (water traces are adsorbed on the pore surface); then, after crystallization, a monotonous increase linked to the growth of the grains [2]. Specific surface area measured by the BET gas adsorption-desorption technique ranges between tens and hundreds of $\mathrm{m}^{2} / \mathrm{g}$, with the highest values reaching 1000-1200 $\mathrm{m}^{2} / \mathrm{g}$ [1,89].

This ideal behavior generally observed for a simple composition can be disturbed by the crystallization sequence, as shown in Figure 4 for the composition $\mathrm{Li}_{2} \mathrm{O} \cdot 2 \mathrm{Al}_{2} \mathrm{O}_{3} \cdot 4 \mathrm{SiO}_{2}$ (LAS), and an optimization of the preparation route is necessary [107]. LAS compositions with keatite (also called $\beta$-spodumene) or high quartz (called $\delta$-spodumene or $\beta$-eucryptite) structures and $\mathrm{MAS}(\mathrm{M}=\mathrm{MgO}$, cordierite) form extensive solid solutions in the $\left(\mathrm{Li}_{2} \mathrm{O} / \mathrm{MgO}\right)-\mathrm{Al}_{2} \mathrm{O}_{3}-\mathrm{SiO}_{2}$ system. Due to their low 
densities, low thermal expansions and their variable melting temperatures, these compounds are used in the form of more or less recrystallized glass ceramics to make cooking table wares, heat exchangers, smartphone windows and telescope mirrors in the form of monolithic pieces. These compositions were also highly studied in the 1990s as potential materials in gas turbines or jet engines in the form of composite matrices, but their corrosion by hot water was too easy [180]. The crystallization/densification due to the departure of «water» can be counterbalanced by the nucleation of a new phase of lower density. The shrinkage and nucleation temperature can be shifted by modifying the chemical route (use of two different metal-organic precursors to introduce the same element, change of hydrolysis parameter, etc.) and the heating cycle. The sintering capacity of the sol-gel prepared 'oxides' is, therefore, directly linked to the porous structure. The heat treatment before shaping (compacting, sedimentation) should not remove these characteristics and must, therefore, be carried out before $500-700{ }^{\circ} \mathrm{C}$ for most oxide compositions.
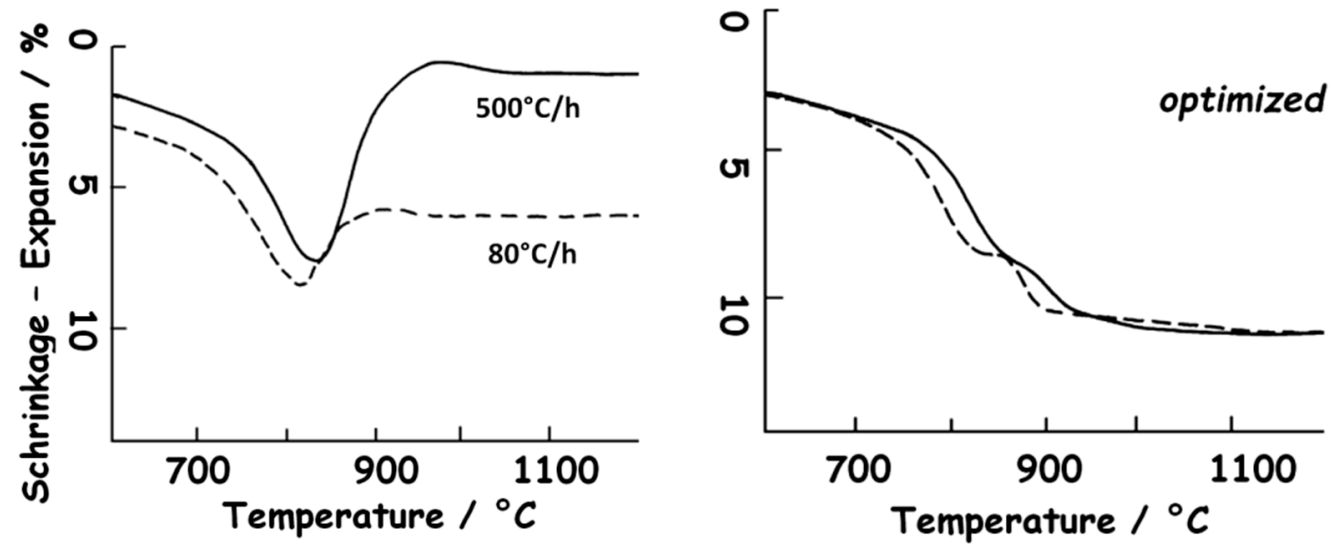

Figure 4. Dilatometric plots of $\mathrm{Li}_{2} \mathrm{O} \cdot 2 \mathrm{Al}_{2} \mathrm{O}_{3} \cdot 4 \mathrm{SiO}_{2}$ (LAS) xerogel into a dense glass ceramic measured for the same composition prepared by different routes, for two heating rates (after [107]).

\subsection{Diffusion}

In the absence of a liquid phase, the welding between grains and their densification require another mechanism - the diffusion of atoms (and/or vacancies) — to form necks and fill the pores with matter. This material transfer mechanism is slow. In comparison, liquid sintering is a quasi-instant phenomenon. The dwell time at the maximum firing temperature is limited to the time necessary to achieve good homogeneity of the temperature in the artefact. On the contrary, when the diffusion of atoms in the solid state is the mechanism of sintering, the dwell time requires several or several tens of hours, depending on the grain size. There are three main diffusion mechanisms [4,5]: (i) solid-state diffusion (in bulk) which first depends on the type of atom, temperature, phase structure, and gradient and distance of diffusion; (ii) the diffusion on the surface of the grain, which depends on the temperature, atom, shape of the surface and gas pressure above the surface (hence the interest in sintering under vacuum, $\mathrm{H}_{2}, \mathrm{O}_{2}$, air, etc.); and (iii) the diffusion in the gas phase (i.e., in the pores and at the external skin of the artefact), which depends on the element, temperature, and pressure. This presentation is a rough approximation (see in $[4,5]$ ) but shows the complexity and the tools that can be used to improve the efficiency of the mechanisms. This also explains why the external surface of a ceramic is necessarily different from the bulk; the large gradients close to the surface enhance the densification. Hence the great interest in preparations which avoid machining of the ceramic object: the very dense layer formed on the surface is preserved.

One of the great interests in the chemical routes is the possibility of activating the different mechanisms at the molecular scale and shifting the densification to a lower temperature. 


\section{Control/Optimization of Structure and Properties}

Control of the structure and composition of the material to be densified (powder, film/coating, and fiber) is, therefore, a key point. Some phases are very stable and, in the case of their formation, it is not possible to eliminate them by thermal treatment. Control of the heterogeneity at the molecular scale by choosing liquid reagents is necessary. The examples of pyrochlore in the preparation of perovskites and zirconia in the preparation of NASICON, etc., are well known. This is particularly true for multivalent non-stoichiometric compounds. The presence of an additional phase lowers the properties, in many cases much more than proportionally, exponentially for dielectrics (Lichtenecker'law) and the exceptional electrical properties are generally linked to the phase with a particular structure composed of two or more sublattices with different types of bonds (covalent, ionic, metallic, Van der Waals, and agostic bonds) [181]. Ferroelectric and piezoelectric properties of perovskites $\left(\mathrm{ABO}_{3}\right)$ are related to the arrangement of $\mathrm{BO}_{6}$ covalent octahedron versus the long-range ordered A-sublattice [26,182]. The superconduction properties of $\mathrm{YBaCuO}$ and similar compounds are linked to the presence (or transition to) of ionic, covalent and metallic-like bonds in the same structure [183-188]. Oxygen vacancies (non-stoichiometry) also control structural distortion and electrical properties and allow for exceptional proton conductivity [181]. Compounds exhibiting the exceptional high conductivity required to serve as a solid electrolyte, i.e., conductivity comparable to that of acidic water or molten salt, have a structure which can be described as an open framework (the thermally stable sublattice) in which an ionic sublattice can melt at low temperature [189-194]: for instance, the subnetwork $\mathrm{Ag}^{+}, \mathrm{Na}^{+}$or $\mathrm{Li}^{+}$ions of $\beta$-alumina, a superionic conductor very representative of this class of materials (also called fast ion conductor), melt at temperatures between -250 and $30^{\circ} \mathrm{C}$ (Figure 5) although the framework melts at temperatures higher than $1800^{\circ} \mathrm{C}[191,192]$. The liquid state and associated conductivity highly depend on the stoichiometry. This example highlights the importance of controlling the composition exactly.
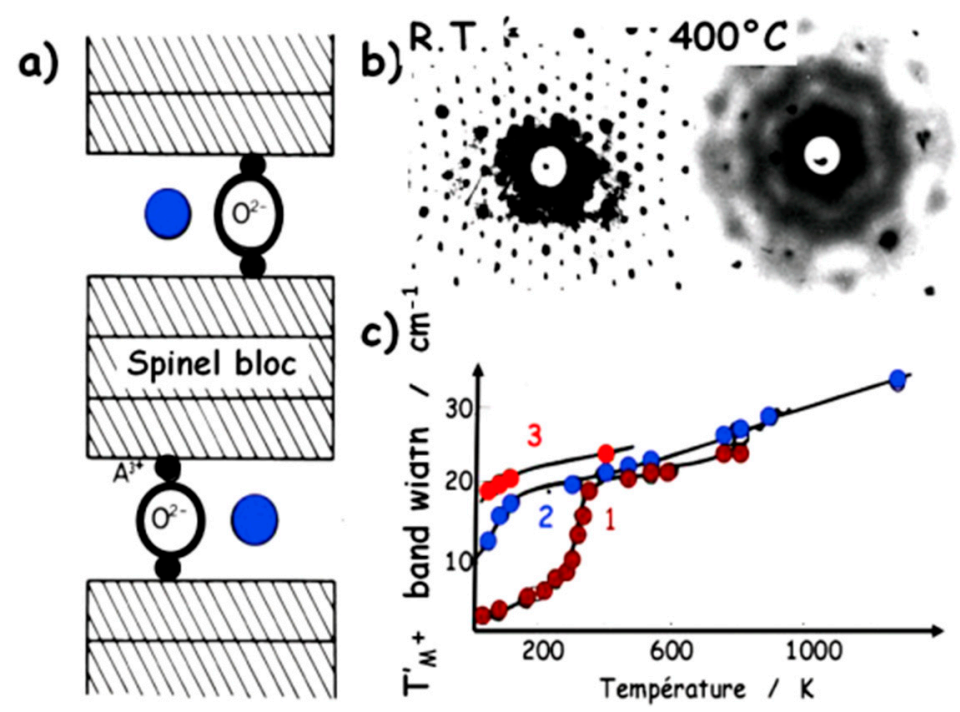

Figure 5. Influence of a small stoichiometry shift. Schematic of the $\beta$-alumina structure: (a) the two sublattices; the dense-packed spinel blocks connected to an Al-O-Al bridge and the open plan allowing for the fast diffusion of conducting cations (in blue); (b) comparison of the X-ray diffuse scattering measured for $\mathrm{Ag} \beta$-alumina before the melting temperature of the $\mathrm{Ag}^{+}$sublattice (R.T., the numerous peaks arise from the superstructure of the $\mathrm{Ag}$ cations before the superionic state) and above $\left(400{ }^{\circ} \mathrm{C}\right.$; the rings come from the liquid state of the $\mathrm{Ag}^{+}$ions; the remaining Bragg peaks come from the host alumina framework); (c) band broadening of the characteristic Raman $\mathrm{T}^{\prime}$ mode of the $\mathrm{Ag}^{+}$ion for ion-rich (1.66), standard (1.25) and stoichiometric $\beta$-alumina $\left(1 \mathrm{Ag}_{2} \mathrm{O} \cdot 11 \mathrm{Al}_{2} \mathrm{O}_{3}\right)$ [191,192]. The shift in the stoichiometry displaces the transition from 'standard' to superionic state for many hundreds of degrees. 
It should be noted that the peculiarity of the structure, such as the open framework, not only promotes fast ion diffusion and, therefore, ion exchange and high conductivity, but also low thermal expansion. Indeed, thermal expansion is an intrinsic phenomenon of the chemical bond; it is the anharmonicity of the chemical potential. The difference in the coefficient of thermal expansion comes from the possibility of counterbalancing the inevitable expansion of the $\mathrm{M}-\mathrm{X}$ bonds with the temperature by rotation of certain bricks of the structure $\left(\mathrm{XO}_{4}\right.$ tetrahedron, $\mathrm{BO}_{6}$ octahedron, etc.). The resulting expansion of the unit cell, and thus all the ceramic, macroscopically, is limited or even suppressed (NASICON-like or cordierite structures) [195-199] or even a contraction can take place (spodumene- and eucrytite-like structures) anisotropically [180,200-209].

Stabilization of the high-temperature-phase (generally the one with the most open framework, the lowest coefficient of thermal expansion and the highest ionic conductivity) results of the quenching of the static and dynamic disorder resulting from the particular synthesis from liquid precursors (in other terms, by quenching the liquid/molecular (dynamically disordered) structure by the way of the gelation $[210,211])$. The dynamic disorder of the gelling entities freezes in a static disorder [187-192]. This disordered structure is determined by geometric constraints; additional annealing can lead to structural changes resulting from (long distance) electrical interactions.

\subsection{Multicomponent Non-Stoichiometric Compounds}

Control of the final composition, structure and properties for each batch requires a minimum volume/weight of material to be prepared. This also imposes that the size of the batch prepared in the laboratory may contribute to the change of scale, from the batch at the laboratory scale to the batch at the test scale. The minimum weight in the laboratory is between $50 \mathrm{~g}$ (e.g., for the preparation of film) and $500 \mathrm{~g}$ (typical weight for the production of ceramic), which implies liters, or more, for the volumes of liquids handled. These values may be considered important for solid-state chemists but minimal for ceramists. The use of smaller batches makes it difficult to optimize the many parameters and makes the reproducibility of the completion of the desired composition, and structure unreliable. Furthermore, the reference sample must be preserved for complementary investigations. Drying the (gel) powder or film is a difficult task, particularly to avoid the formation of powdered aggregates or the formation of cracks in films and monoliths.

As indicated above, research on the chemical routes of preparation of ceramics from liquids, in particular organic precursors, dates from the 1970s to the 1980s [1,59-61,94,102] or even before for the composition of a single metallic element (silica, alumina, and nuclear fuels). Their use remains very limited, since many ceramists have applied the recipes, traditionally used for standard ceramic powders, to chemically prepared powders and concluded that these chemically prepared powders are not good for sintering. Before shaping, a heat treatment (to obtain the chamotte in French, grog in English) was carried out, but the temperature was not convenient. Indeed, if the temperature is not the required temperature, many advantages, particularly the sintering at low temperature, are lost.

The difficulties in reaching a target composition chemically (via the liquid route) arise from the different behaviors of the elements as a function of the chemical bonds that they form during the process. A small composition shift drastically modifies the electrical properties [26,27,38-40,189-193,211-215]. Ions are easily lost (when liquids are removed, and when adsorbed on the surface of the container). This is the case for fluxes (alkaline and earth-alkaline, and lead cations). Fortunately, these ions diffuse rapidly, and promote the formation of liquid phases. The heterogeneity of the distribution before firing is, therefore, not detrimental. The multicomponent composition to be prepared with precise control of the composition was PLZT-first by the inorganic chemical route $[66,67]$ and then by the alkoxide route $[64,65] . \mathrm{PbO}$, a highly volatile oxide, acts as a liquid-phase former at the grain boundary, which helps hot-pressing sintering up to $99.8 \%$ but requires a control and trapping of excess volatile $\mathrm{PbO}$ [65]. Complete removal of the residual $\mathrm{PbO}$ from the grain boundary is necessary to achieve optical clarity. The fast diffusion of lead ions allows certain heterogeneity in the precursors and, therefore, its addition 
in powder form in the alkoxide mixture is possible; further acetic acid added for the hydrolysis of water dissolves a large part of the $\mathrm{PbO}$ powder [65].

A second difficulty comes from elements which 'precipitate' too rapidly in an uncontrolled way. For instance, pure aluminum-sec butoxide reacts instantaneously with water but tributylphosphate is hardly hydrolyzed. If stable phases such as zirconia or $\mathrm{ZrSiO}_{4}, \mathrm{ZrP}_{2} \mathrm{O}_{7}$, and $\mathrm{PbZr}_{2} \mathrm{O}_{7}$ are formed, they will react with difficulty and cannot be eliminated [92,99]. The transition metal alkoxides also react with each other [62], which leads to local heterogeneity. Other important criteria are the cost of the chemicals, their handling conditions and the reliability regarding their composition. This is especially true for liquid chemicals, especially those that are diluted or contain extra minor compounds. For example, alcohol is often added to the alkoxides. The content of elements in each bottle, barrel, etc., must be checked. A small volume of alkoxide is hydrolyzed and a thermal analysis (TGA or weight measurements) is carried out. The phase(s) obtained are controlled, and the elemental composition and structure(s) are formed. Rules of three then allow the composition calculation to be adjusted.

Chemical routes lead to very fine (and porous) powders (rapid drying from a large excess of liquid 'solvent'; the volume excess and the procedure of removal of the liquid change the characteristics of the powder) or monoliths (sedimentation/peptization of sols, slow hydrolysis/evaporation of the liquid, etc.). The stage of liquid elimination is difficult and risky, such as the loss of certain elements, risk of uncontrolled/spontaneous ignition, formation of hard aggregates, cracks, etc. Optimization of the powder is necessary by milling/grinding and sieving to eliminate the aggregates, humidity control, storage under controlled atmosphere, efflorescence, etc.

Complex techniques have thus been used, for example by direct control of the viscosity of the liquid precursor for spinning, (spin-)coating, (freeze or heat) spray-drying and granulation, (pressure-assisted) infiltration to prepare films, fibers or to infiltrated porous forms (mats, textiles, pre-fired porous monolith, etc.) combining oxides, carbon, carbides, metal, etc. [9,11-13,29,60,81,83,84,102,114,131-133,216-229].

\subsection{Composites (Particulate, Fibers, Metal/Oxides)}

Historically, the first use of liquid precursor to make a coating was the traditional method of enameling: a powder dispersed in water or in an organic medium which will give a viscous liquid is deposited on the body (porous or non-porous) of pottery and melted by heating [230]. The wettability and viscosity must be adjusted to form a uniform thickness when cooling the glassy coating; it must be free from cracks and have the required colored decoration [231]. The technique has been transposed to advanced ceramic compositions with dipping/soaking, doctor blade deposition, screen printing, etc. $[1,10-13,17,232]$. In general, the addition of polymers is necessary to control the viscosity (in the green state), but after, removing the polymer is not easy and can counterbalance the densification of heating. Direct manipulation of the viscosity of the mixture of liquid precursors offers an alternative and most of the ceramic fibers are thus prepared (alumina, mullite, $\mathrm{SiC}$, and C) $[33,121,233,234]$. Composites made up of fiber assemblies (1D, 2D, mats, woven and textile preforms) or a dispersion of a second phase in a matrix (particulates) are prepared by infiltration of a liquid precursor or by vapor-phase deposition. $[114,121,133,148]$. Combinations of techniques are possible as well as the preparation of hierarchically reinforced or functionally graded composites [148].

\subsection{Tools/Requirements for Minimizing the Temperature of Full Densification}

As indicated above, the specificity of the preparation of ceramics from metal-organic products or more precisely from hybrid chemicals with organic branches and metallic elements (or metalloids) is the association of densification, with formation on heating, of an inorganic glassy/amorphous polymer network when some elements (mainly water and protons, $\mathrm{CO}_{2}$, etc.) are volatilized. During this transition, the material is very reactive such that it can be used for reaction with gas $\left(\mathrm{O}_{2}, \mathrm{NH}_{3}\right)$ to transform into oxide, nitride, etc., or to increase densification or minimize the temperature of sintering [1]. Generally, nucleation of crystals also occurs. On the contrary, after this reaction, whatever the submicron size of the grain, generally less than $0.5 \mu \mathrm{m}$, their sintering capacity can be weaker and require a new attrition 
to be able to sinter properly. Figure $6 \mathrm{a}, \mathrm{b}$ show an example of lowering the sintering temperature of NASICON solid electrolyte ceramic $\left(\mathrm{Na}_{1+\mathrm{x}} \mathrm{Zr}_{2} \mathrm{Si}_{\mathrm{x}} \mathrm{P}_{3-\mathrm{x}} \mathrm{O}_{12}\right)$, while optimizing the preparation and shaping of the powder gel under pressure (that is to say, in the green state) $[14,92,99]$. In fact, densification is only effective if there is continuity of contacts between the grains. Shaping techniques that preserve/promote contacts are welcome, such as 'green' pressing or sedimentation techniques. For complete densification in the green state (the pellet is pressed for $10 \mathrm{~h}$ at $350 \mathrm{MPa}$ and appears translucent after; specific area of the gel powder measured by BET instrument: $\sim 80 \mathrm{~m}^{2} / \mathrm{g}$ ), complete densification $(>97 \%)$ is achieved at $700{ }^{\circ} \mathrm{C}$ instead of $1200^{\circ} \mathrm{C}$ for standard oxide powder compacts, with the densification induced by nucleation and the departure of the protons stabilizing the porous state (Figure 3). However, the densification decreases for firing between 800 , and $1000^{\circ} \mathrm{C}$, with the crystallization of different structures of NASICON [211-213]. In contrast, the full densification of the conventionally compacted gel pellet $(2 \mathrm{~min})$ is reached at $800{ }^{\circ} \mathrm{C}$ and the disturbance induced by crystallization is limited. This example, like the one reported for LAS (Figure 4), shows the many parameters to be adjusted to obtain densification of a complex composition at low temperature (here $\mathrm{x}=2$; see the formula above). The densification rate strongly depends not only on the densification in the green state but also on the precursors and the procedure conducted in the preparation of the gel $[92,99,211]$, in particular to avoid the formation of zirconia precipitates that cannot be eliminated. The mathematical techniques of the Latin Squares are then useful for classifying the parameters to be optimized.

The decrease in density above $1200{ }^{\circ} \mathrm{C}$ results from abnormal grain growth, a typical phenomenon observed for sol-gel-prepared compositions, due to the absence of impurity at the grain boundary. It is worth mentioning that this defect in densification of the ceramic offers the possibility of synthesizing (small) single crystals of incongruous fusion composition such as NASICON [235]. No other method has been demonstrated to prepare these single crystals.
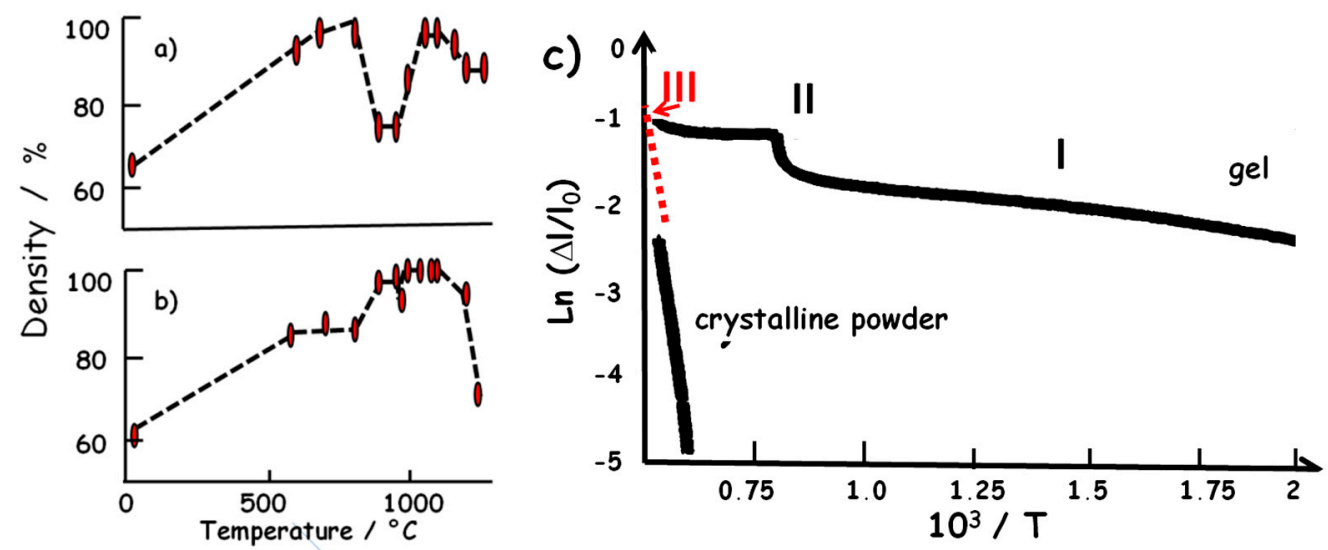

Figure 6. Density (in \% of the theoretical density deduced from the unit-cell parameter measured by $\mathrm{XRD}$ ) as a function of the firing temperature and of the 'green state' pressure sintering of Nasicon $(x=2)$ pellets $(\mathbf{a})$, high compaction obtained for $10 \mathrm{~h}$; (b), medium compaction for 2 min (after [14]); (c), comparison of the densification expressed in logarithmic ratio of the thermal expansion $\left(\Delta \mathrm{l} / \mathrm{l}_{0}\right)$ versus 1000/T (T in K) for the compacted mullite gel (regime I) and the standard (micronic) commercial powder (Baikowsky, France). II, nucleation-densification; III, standard regime, (after [236]).

Figure $6 c$ confirms, with the example of mullite, the great advantage of sol-gel preparation $[88,97,236]$ : a high preliminary densification can be obtained in the gel state and, therefore, the number and surface of contacts are high and the density of the phase obtained after nucleation-densification is very close to full density. It is obvious that the densification mechanisms of a (xero)gel and a crystalline powder are different, below $\sim 1200-1300{ }^{\circ} \mathrm{C}$ for mullite. The transition towards standard mechanisms of sintering is only initiated above $1200^{\circ} \mathrm{C}$ (regime III).

Sintering to complete the densification of a powder based on isotropic grains is much easier than that of an assembly of hard platelets or needles. Alternative techniques such as microwave heating, 
which induces a strong orientation of the anisotropic grains, may help. This has been demonstrated for Na $\beta$-alumina using sol-gel prepared powders [103,237-240] and other ionic conductors [241]. Indeed, there is a strong coupling in the $\mathrm{GHz}$ range between the electric field of the microwave and the relaxation of the conducting ions $[103,242,243]$. Another alternative technique is the coating of hard and anisotropic grains with a gel which will lubricate the grain motion/re-arrangement during the pressing step in the green state and allows fairly good densification $[147,148]$.

\subsection{Complex Electrochemical Devices}

The preparation of an electrochemical cell in the solid state (for sensor, battery, fuel cell, electrolyzer or $\mathrm{CO}_{2}$ converter, purification of isotopes) requires the association of at least two current collectors and two electrodes (anode and cathode, electron conductor) on either side of the electrolyte (ion conductor but electron insulator). Some of them must be dense and thin (the electrolyte), the others rather porous (the electrodes in order to maximize the contact surface between the electrolyte, the electrodes, and the atmosphere for fuel cells and the electrolyzer/converter). Indeed, when a gas is used, the electrodes must be porous to maximize the triple points required for redox reactions (ions and electrons) in the solid and gas phases (see for example [244-248]). The core or the substrate (the dense electrolyte or one of the electrodes or one of the current collectors, depending on the strategy for the cell assembly: the type of structure, in the form of stacked layers or tube) is prepared first at the highest temperature. The other materials must be deposited and heated at a temperature of $\sim 200^{\circ} \mathrm{C}$ lower to preserve the geometry and the structure of the substrate. The economic criteria must be compatible to technical criteria. Obviously, physical preparation methods such as atomic layer deposition (ALD) [249-251], plasma vapor deposition (PVD) [252], and ion implantation [253,254] can be used to deposit thin layers ( $\mathrm{a}$ few to a few tens of microns) on a substrate. These methods are effective for making miniaturized objects (sensors) [255] but are potentially less competitive for large-scale energy production, conversion and storage devices than sol-gel and chemical routes [255-259]. The ceramic route is inexpensive and the chemical routes are suitable for the preparation of fine powders (for shaping, screen printing, laser sintering, etc.) or films directly [17,35,36,106,131,132,172,259-265]. The firing temperatures must be similar. It is necessary to lower the temperature of sintering of certain materials. This is especially true for additional materials such as the intermediate layer acting as a diffusion barrier which should be added between the electrolyte layer and the electrodes to prevent unwanted diffusion of certain ions (and phase and conductivity degradation) under the electric field during electrochemical cycles [260-264].

\section{Conclusions}

We have highlighted the interest in syntheses starting from liquid reagents to obtain mixing at the molecular scale. This minimizes the diffusion length for the atoms to react together and to form the desired phases. High green densities are obtained and the 'low' temperatures are thus sufficient to achieve full densification of the ceramic. The mastery of rheology is very useful for shaping (e.g., the preparation of fibers) and polymeric routes allow 3D printing. Hybrid methods in which certain elements are incorporated by metal-organic reagents and other methods in the form of 'standard' powder make it possible to limit costs, and the volume of effluents to be treated. The residual impurities of 'standard' raw materials limit the exaggerated abnormal growth of the grains. The counterpart is the number of parameters to explore and optimize, in particular to control phase structure and microstructure. It is, therefore, important to work with the mentality of a ceramist and not a chemist. It is clear that the need to minimize the energy required for manufacturing will lead to the development of chemical methods for the synthesis of ceramics, particularly in layers.

Funding: This research received no external funding.

Acknowledgments: The author thanks all colleagues and students involved in the 50 years of activity in the field.

Conflicts of Interest: The authors declare no conflict of interest. 


\section{References}

1. Colomban, P. Gel Technology in Ceramics, Glass-Ceramics and Ceramic-Ceramic Composites. Ceram. Int. 1989, 15, 23-50. [CrossRef]

2. Colomban, P. Nano/micro-structure and Property Control of Single and Multiphase Materials. In Chemical Processing of Ceramics, 2nd ed.; Komarneni, S., Lee, B., Eds.; CRC Press: Boca Raton, FL, USA, 2005; Chapter 12; pp. 303-339.

3. Colomban, P. Natural nanosized raw materials and Sol-Gel technology: The base of pottery since millennia. In Nanoscience and Cultural Heritage; Dillmann, P., Bellot-Gurlet, L., Nenner, I., Eds.; Springer-Atlantis: Amsterdam, The Netherlands, 2016; pp. 59-73.

4. Kingery, W.D.; Bowen, H.K.; Uhlmann, D.R. Introduction to Ceramics, 2nd ed.; J. Wiley \& Sons: New-York, NY, USA, 1976.

5. Gerard-Hirne, J.; Rigaud, J.; Cizeron, G.; Peyssou, J.; Godron, Y.; Jouenne, C.A.; Gion, L.; Dumoulin, G.; Pastor, H.; Vassiliev, A.; et al. Le Frittage. Extraits de L'Industrie Céramique, Special Issue; Institut de Céramique Française: Sèvres, France, 1975.

6. Cooper, E. Ten Thousand Years of Pottery, 4th ed.; University of Pennsylvania Press: Philadelphia, PA, USA, 2000.

7. Richerson, D.W. The Magic of Ceramics; The American Ceramic Society: Westerville, OH, USA, 2000.

8. Levin, E.M.; Robin, C.R.; McMurdie, H.F. Phase Diagrams for Ceramists; The American Ceramic Society: Columbus, OH, USA, 1964.

9. Segal, D. Chemical Synthesis of Advanced Ceramic Materials; Cambridge University Press: Cambridge, UK, 1989.

10. Komarneni, S.; Lee, B. (Eds.) Chemical Processing of Ceramics, 2nd ed.; CRC Press: Boca Raton, FL, USA, 2005.

11. Klein, L.C. Sol-Gel Technology; Noyes Publications: Park Ridge, IL, USA, 1988.

12. Pierre, A.C. Introduction to Sol-Gel Processing; Kluwer: Boston, MA, USA, 1998.

13. Pierre, A.C. Introduction to Sol-Gel Processing; Springer: Cham, Switzerland, 2020.

14. Bouquin, O.; Perthuis, H.; Colomban, P. Low Temperature Sintering and Optimal Physical Properties: A Challenge the NASICON Ceramics Case. J. Mater. Sci. Lett. 1985, 4, 956-959. [CrossRef]

15. Jouenne, C.-A. Traité de Céramiques et Matériaux Minéraux; Edition Septima: Paris, France, 1980.

16. Reed, J.S. Principles of Ceramics Processing; Wiley Interscience: New York, NY, USA, 1995.

17. Perthuis, H.; Velasco, G.; Colomban, P. Na ${ }^{+}$and $\mathrm{Li}^{+}$NASICON Superionic Conductors Thick Films. Jpn. J. Appl. Phys. 1984, 23, 534-543. [CrossRef]

18. Burke, J.E. Uranium Dioxide Nuclear Fuel. In High-Technology Ceramics. Past, Present, and Future. The Nature of Innovation and Change in Ceramic Technology; Kingery, W.D., Ed.; Ceramics and Civilization Series; The American Ceramic Society: Westerville, OH, USA, 1986; Volume 3, pp. 239-258.

19. Baden Fuller, A.J. Ferrites at Microwave Frequencies; IEE Electromagnetic Waves Series 23; Peter Peregrinus Ltd. on Behalf of the IEE: London, UK, 1987.

20. Pujes, J.-P. A Century of Electronics. History of the Thales Group; Thales: Paris, France, 2005.

21. Weber, J.-M. Un Demi-Siècle D'aéronautique en France. Etudes et Recherches; Tome 1, Les Cahier du CHEAr, CHEAr: Paris, France, 2008.

22. Ault, N.N. Silicon-Carbide-Its Progression as a Refractory Material. In High-Technology Ceramics. Past, Present, and Future. The Nature of Innovation and Change in Ceramic Technology; Kingery, W.D., Ed.; Ceramics and civilization Series; The American Ceramic Society: Westerville, OH, USA, 1986; Volume 3, pp. 219-230.

23. Jack, K.H. Silicon Nitride, Sialons, and Related Ceramics. In High-Technology Ceramics. Past, Present, and Future. The Nature of Innovation and Change in Ceramic Technology; Kingery, W.D., Ed.; Ceramics and Civilization Series; The American Ceramic Society: Westerville, OH, USA, 1986; Volume 3, pp. 259-288.

24. Smith, P.L.; White, J. Basic Refractories and the Emergence of the Steel Industry. In High-Technology Ceramics. Past, Present, and Future. The Nature of Innovation and Change in Ceramic Technology; Kingery, W.D., Ed.; Ceramics and Civilization Series; The American Ceramic Society: Westerville, OH, USA, 1986; Volume 3 , pp. 181-209.

25. Berg, M. Aluminum Oxide Spark Plug Insulators. In High-Technology Ceramics. Past, Present, and Future. The Nature of Innovation and Change in Ceramic Technology; Kingery, W.D., Ed.; Ceramics and Civilization Series; The American Ceramic Society: Westerville, OH, USA, 1986; Volume 3, pp. 211-217. 
26. Cross, L.E.; Newnham, R.E. History of Ferroelectrics. In High-Technology Ceramics. Past, Present, and Future. The Nature of Innovation and Change in Ceramic Technology; Kingery, W.D., Ed.; Ceramics and Civilization Series; The American Ceramic Society: Westerville, OH, USA, 1986; Volume 3, pp. 289-305.

27. Haertling, G.H. Ferroelectric Ceramics: History and technology. J. Am. Ceram. Soc. 1999, 82, 797-818. [CrossRef]

28. Stetson, H.W. Multilayer Ceramic Technology. In High-Technology Ceramics. Past, Present, and Future. The Nature of Innovation and Change in Ceramic Technology; Kingery, W.D., Ed.; Ceramics and Civilization Series; The American Ceramic Society: Westerville, OH, USA, 1986; Volume 3, pp. 307-322.

29. Hench, L.L.; Ulrich, D.R. (Eds.) Ultrastructure Processing of Ceramics, Glasses and Composites; Wiley: New York, NY, USA, 1984.

30. Hench, L.L. Bioceramics: From Concept to Clinic. J. Am. Ceram. Soc. 1991, 74, 1487-1510. [CrossRef]

31. Hench, L.L. (Ed.) An Introduction to Bioceramics, 2nd ed.; Imperial College Press: London, UK, 2013.

32. Bill, J.; Aldinger, F. Precursor-derived covalent ceramics. Adv. Mater. 1995, 7, 775-787. [CrossRef]

33. Riedel, R.; Mera, G.; Hauser, R.; Klonczynski, A. Silicon-based polymer-derived ceramics: Synthesis properties and applications-A review. J. Ceram Soc. Jpn. 2006, 114, 425-444. [CrossRef]

34. Jones, J.R. Review of Bioactive glass. Acta Biomater. 2013, 9, 4457-4486. [CrossRef]

35. Miguez-Pacheco, V.; Hench, L.L.; Boccaccini, A.R. Bioactive glasses beyond bone and teeth: Emerging applications in contact with soft tissues. Acta Biomater. 2015, 13, 1-15. [CrossRef]

36. Cox, S.C.; Thornby, J.A.; Gibbons, G.J.; Williams, M.A.; Mallick, K.K. 3d printing of porous hydroxyapatite scaffolds intended for use in bone tissue engineering applications. Mater. Sci. Eng. C 2015, 47, 237-247. [CrossRef]

37. Chai, W.; Wei, Q.; Yang, M.; Ji, K.; Guo, Y.; Wei, S.; Wang, Y. The printability of three water based polymeric binders and their effects on the properties of 3D printed hydroxyapatite bone scaffold. Ceram. Int. 2020, 46, 6663-6671. [CrossRef]

38. Geus, J.W. Fast ion transport in solids: Solid state batteries and devices. In Proceedings of the NATO Sponsored Advanced Study Institute on Fast Ion Transport in Solids, Belgirate, Italy, 5-15 September 1972; North Holland-American Elsevier: Amsterdam, The Netherlands, 1973.

39. Marrony, M. Proton Conducting Ceramics, From Fundamental to Applied Research; Pan Stanford Publishing: Singapore, 2016.

40. Colomban, P. Proton conductors and their applications: A tentative historical overview of the early researches. Solid State Ionics 2019, 334, 125-144. [CrossRef]

41. Rabe, T.; Linke, D. Attrition milling of Silicon-Nitride powder under conditions for minimal impurity pickup. Ceram. Int. 1992, 18, 161-166. [CrossRef]

42. Houivet, D.; El Fallah, J.; Haussonne, J.-M. Dispersion and grinding of oxide powders into an aqueous slurry. J. Am. Ceram. Soc. 2002, 85, 321-328. [CrossRef]

43. Balakrishna, P.; Murty, B.N.; Ratnam, D.V.; Anuradha, M.; Ganguly, C. Light attrition of uranium dioxide powder. Ceram. Int. 2003, 29, 99-105. [CrossRef]

44. Mestl, G.; Srinivasan, T.K.K.; Knozinger, H. Mechanically Activated $\mathrm{MoO}_{3}$. 3. Characterization by vibrational Spectroscopy. Langmuir 1995, 11, 3795-3804. [CrossRef]

45. Michel, D.; Mazerolles, L.; Begin Colin, S. Mechanical alloying of oxides. Ann. Chim. Sci. Mater. 1997, 22, 403-416.

46. Sengupta, L.C.; Synowcyznski, J.; Chiu, L.H. Investigation of the effect of particle size on the optical and electronic properties of $\mathrm{Ba}_{1-x} \mathrm{Sr}_{x} \mathrm{TiO}_{3}$. Integr. Ferroelectr. 1997, 17, 287-296. [CrossRef]

47. Kaczmarek, W.A. Phase stability in non-stoichiometric iron-cobalt oxides prepared by mechanochemical activation. In Synthesis and properties of Mechanically Alloyed and Nanocrystalline Materials; Fiorani, D., Magini, M., Eds.; PTS 1 and 2-ISMANAM-96; Mater. Sci. Forum: Bäch, Switzerland, 1997; Volume 235-238, Part 1 and 2; pp. 109-114.

48. Rickerby, D.G.; Jiang, J.Z.; Lin, R.; Morup, S. Transmission electron microscopy studies of mechanical alloying in the immiscible $\mathrm{Fe}_{2} \mathrm{O}_{3}-\mathrm{SnO}_{2}$ system. In Mechanically Alloyed, Metastable and Nanocrystalline Materials; Baro, M.D., Surinach, S., Eds.; Mater. Sci. Forum: Bäch, Switzerland, 1998; Volume 269-272, Part 1; pp. 351-356. 
49. Nivoix, V.; Gaffet, E.; Bernard, F.; Gillot, B. Mechanical activation of iron and vanadium oxides in order to obtain nanometric vanadium ferrite similar to a soft chemistry compound. C. R. Acadm. Sci. Ser. II C Chim. 1998, 1, 183-189.

50. Kong, L.B.; Zhang, T.S.; Ma, J.; Boey, F. Progress in synthesis of ferroelectric ceramic materials via high-energy mechanochemical technique. Progr. Mater. Sci. 2008, 53, 207-322. [CrossRef]

51. Janot, R.; Gherard, D. Ball-milling in liquid media-Applications to the preparation of anodic materials for lithium-ion batteries. Progr. Mater. Sci. 2005, 50, 1-92. [CrossRef]

52. Kong, L.B.; Ma, J.; Huang, H.; Zhang, R.F.; Que, W.X. Barium titanate derived from mechanochemically activated powders. J. Alloys Compd. 2002, 337, 226-230. [CrossRef]

53. Suryanarayana, C. Mechanical alloying and milling. Progr. Mater. Sci. 2001, 46, 1-184. [CrossRef]

54. Chi, T.T.K.; Gouadec, G.; Colomban, P.; Wang, G.; Mazerolles, L.; Thanh, D.X.; Liem, N.Q. Off Resonance Raman Spectroscopy of Wurtzite Cds Ground to the nanoscale: Discrimination between structural and size-related effects. J. Raman Spectrosc. 2011, 42, 1007-1015. [CrossRef]

55. Dislich, H. Sol-Gel 1984-2004. J. Non-Crystall. Solids 1985, 73, 599-612. [CrossRef]

56. Roy, R. Gel route to homogeneous glass preparation. J. Am. Ceram. Soc. 1969, 52, 344-347. [CrossRef]

57. Yoldas, B.E. Effect of variation in polymerized oxides on sintering and crystalline transformations. J. Am. Ceram. Soc. 1977, 65, 387-391. [CrossRef]

58. Sakka, S.; Kamiya, K. Glasses from metal alcoholates. J. Non-Crystall. Solids 1980, 42, 403-422. [CrossRef]

59. Mazdiyasni, K.S. Powder synthesis from metal-organic precursors. Ceram. Int. 1982, 8, 42-56. [CrossRef]

60. Johnson, D.W., Jr. Sol-Gel processing of ceramic and glass. Am. Ceram. Soc. Bull. 1985, 64, 1587-1602.

61. Colomban, P. Chemical Routes and Sol-Gel Processes: The Elaboration of Ultrafine Powders. L'Industrie Céramique 1985, 792, 186-196.

62. Bradley, D.C.; Mehrotra, R.C.; Gaur, D.P. Metal Alkoxides; Academic Press: London, UK, 1978.

63. Okamura, H.; Bowen, H.K. Preparation of Alkoxides for the Synthesis of Ceramics. Ceram. Int. 1986, 12, 161-171. [CrossRef]

64. Snow, G. Fabrication of transparent electronic PLZT ceramics by atmosphere sintering. J. Am. Ceram. Soc. 1973, 56, 91-96. [CrossRef]

65. Colomban, P. Frittage de céramiques transparentes PLZT. L'Industrie Céramique 1976, 697, 531-535.

66. Haertling, G.H.; Land, C.E. Hot-Pressed (Pb,La) $(\mathrm{Zr}, \mathrm{Ti}) \mathrm{O}_{3}$ Ferroelectric Ceramics for Electrooptic Applications. J. Am. Ceram. Soc. 1971, 54,1-11. [CrossRef]

67. Thomson, J. Chemical Preparation of PLZT Powders from aqueous Nitrate Solutions. Am. Ceram. Bull. 1973, 52,368 .

68. Iller, R.K. The Chemistry of Silica; Wiley: New York, NY, USA, 1974.

69. Davidovits, J. Geopolymers-Inorganic polymeric new materials. J. Therm. Anal. 1991, 37, $1633-1656$. [CrossRef]

70. Duxson, P.; Provis, J.L.; Luley, G.C.; Mallicoat, S.W.; Kriven, W.M.; van Deventer, J. Understanding the relationship between Geopolymer composition, microstructure and mechanical properties. Colloid. Surf. A 2005, 269, 47-58. [CrossRef]

71. Rowles, M.; O'Connor, B. Chemical optimisation of the compressive strength of aluminosilicate geopolymers synthetised by sodium silicate activation of metakaolinite. J. Mater. Chem. 2003, 13, 1161-1165. [CrossRef]

72. Bell, J.L.; Driemeyer, P.E.; Kriven, W.M. Formation of ceramics from meta-kaolin-based Geopolymers. Part I: Cs-based Geopolymer. J. Am. Ceram. Soc. 2009, 92, 1-8. [CrossRef]

73. Bell, J.L.; Driemeyer, P.E.; Kriven, W.M. Formation of ceramics from meta-kaolin-based Geopolymers. Part II: K-based Geopolymer. J. Am. Ceram. Soc. 2009, 92, 607-615. [CrossRef]

74. Duxson, P.; Provis, J.L.; Lukey, G.C.; Van Deventer, J.S.J. The Role of Inorganic Polymer Technology in the Development of Green Concrete. Cem. Concr. Res. 2007, 37, 1590-1597. [CrossRef]

75. Matijevic, E. Monodispersed colloids: Art and Science. Langmuir 1986, 2, 12-20. [CrossRef]

76. Lisiecki, I.; Pileni, M.P. Synthesis of Well-Defined and Low Size Distribution Cobalt Nanocrystals: The Limited Influence of Reverse Micelles. Langmuir 2003, 19, 9486-9489. [CrossRef]

77. Costanzo, S.; Simon, G.; Ricciardi, J.; Colomban, P.; Lisiecki, I. Solvent Effect on AOT Surfactant Solvation-A Facile Strategy to Control the Size of Co Nanocrystals and their 2D/3D ordering. J. Phys. Chem. Part C 2016, 120, 22054-22061.

78. Segal, D. Chemical synthesis of ceramic materials. J. Mater. Chem. 1997, 7, 1297-1305. [CrossRef] 
79. Pechini, M. Method of Preparing Lead and Alkaline-Earth Titanates and Niobates and Coating Method Using the Same to Form a Capacitor. U.S. Patent No. 3330 697, 11 July 1967.

80. Touati, F.; Gharbi, N.; Colomban, P. Structural Evolution in Polyolysed Hybrid Organic-Inorganic Alumina Gels. J. Mater. Sci. 2000, 35, 1565-1570. [CrossRef]

81. Zarzycki, J.; Prassas, M.; Phalippou, J. Synthesis of Glasses from Gels: The Problem of Monoloithic Gels. J. Mater. Sci. 1982, 17, 3371-3379. [CrossRef]

82. Colomban, P.; Boilot, J.-P. Polymètres inorganiques (xerogels et verres) dans les systèmes $\mathrm{M}_{2} \mathrm{O}-\mathrm{M}^{\prime} \mathrm{O}_{2} \mathrm{SiO}_{2}-\mathrm{P}_{2} \mathrm{O}_{5} \mathrm{X}_{2} \mathrm{O}_{3}$. Rev. Chim. Minérale 1985, 22, 235-255.

83. Colomban, P. Sol-gel control of the micro/nanostructure of functional ceramic-ceramic and metal-ceramic composites. J. Mater. Res. 1998, 13, 803-811. [CrossRef]

84. Colomban, P. Tailoring and control of the micro/nanostructure of functional (FGM) CMC's and MMC's. J. Korean Ceram. Soc. 1999, 5, 55-72.

85. Karlin, S.; Colomban, P. Phase diagram, short range structure and amorphous phases in the $\mathrm{ZrO}_{2}-\mathrm{GeO}_{2}\left(-\mathrm{H}_{2} \mathrm{O}\right)$ system. J. Am. Ceram. Soc. 1999, 82, 735-741. [CrossRef]

86. Boilot, J.-P.; Colomban, P.; Blanchard, N. Formation of Superionic Gels and Glasses by Low Temperature Chemical Polymerization. Solid State Ionics 1983, 9/10, 639-643. [CrossRef]

87. Vendange, V.; Colomban, P.; Larché, F. Pore size and liquid impregnation of microporous aluminosilicate gels and glasses. Microporous Mater. 1996, 5, 389-400. [CrossRef]

88. Colomban, P.; Vendange, V. Sintering of alumina and mullite prepared by slow hydrolysis of alkoxides: The role of the protonic species and of pore topology. J. Non-Crystall. Solids 1992, 147/148, 135-140. [CrossRef]

89. Vendange, V.; Colomban, P. How to tailor the porous structure of alumina and aluminosilicate gels and glasses. J. Mater. Res. 1996, 11, 518-528. [CrossRef]

90. Vendange, V.; Colomban, P. Determination of the hydroxyl group content in gels and porous "glasses" issued of alkoxide hydrolysis by combined TGA and BET analysis. J. Porous Mater. 1996, 3, 193-200. [CrossRef]

91. Vendange, V.; Colomban, P. Densification mechanisms of alumina, aluminosilicates and aluminoborosilicates gels, glasses and ceramics. J. Sol-Gel Sci. Technol. 1994, 2, 407-411. [CrossRef]

92. Perthuis, H.; Colomban, P. Sol-gel Routes Leading to NASICON Ceramics. Ceram. Int. 1986, 12, 39-52. [CrossRef]

93. Colomban, P. Sol-Gel Synthesis and Densification of NASICON Powders. Adv. Ceram. 1987, 21, $139-154$.

94. Blanchard, N.; Boilot, J.-P.; Colomban, P.; Pouxviel, J.C. New glasses from metal organic precursors Preparation and Properties. J. Non-Crystall. Solids 1986, 82, 205-209. [CrossRef]

95. Pouxviel, J.-C.; Boilot, J.-P. Gels from a double alkoxide: $(\mathrm{BuO})_{2}$-Al-O-Si-(OEt) 3 . J. Mater. Sci. 1989, 24 , 321-327. [CrossRef]

96. Colomban, P. Structure of Oxide Gels and Glasses by IR and Raman Scattering: I. Aluminas. J. Mater. Sci. 1989, 24, 3002-3010. [CrossRef]

97. Colomban, P. Structure of Oxide Gels and Glasses by IR and Raman Scattering: II. Mullites. J. Mater. Sci. 1989, 24, 3011-3020. [CrossRef]

98. Bruneton, E.; Colomban, P. Influence of hydrolysis conditions on crystallization, phase transitions and sintering of zirconias prepared by alkoxide hydrolysis. J. Non-Crystall. Solids 1992, 147/148, 201-205.

99. Perthuis, H.; Colomban, P. Well Densified NASICON-type Ceramics elaborated using Sol-Gel Process and Sintering at Low Temperatures. Mater. Res. Bull. 1984, 19, 621-631. [CrossRef]

100. Colomban, P. Sol-Gel Routes and Proton Conductors. In Sol-Gel Processing for Conventional and Alternative Energy; Aparicio, M., Jitianu, A., Klein, L.C., Eds.; Springer Science + Business Media: New York, NY, USA, 2012; Chapter 4; pp. 59-71.

101. Dunn, B.; Zink, J.I. Optical-Properties of Sol-Gel Glasses doped with organic molecules. J. Mater. Chem. 1991, 1, 903-913. [CrossRef]

102. Roy, R. Ceramics by the solution-sol-gel route. Science 1987, 238, 1664-1669. [CrossRef]

103. Colomban, P.; Badot, J.C. Elaboration de céramiques superconductrices ioniques anisotropes par chauffage microonde. Mater. Res. Bull. 1978, 13, 135-139. [CrossRef]

104. Lenfant, P.; Plas, D.; Ruffo, M.; Boilot, J.-P.; Colomban, P. Céramiques d'alumine $\beta$ et de ferrite $\beta$ pour sonde à protons. Mater. Res. Bull. 1980, 15, 1817-1827. [CrossRef]

105. Boilot, J.P.; Colomban, P. Superionic Conductors from the Sol-Gel Process. In Sol-Gel Technology; Klein, L.C., Ed.; NOYES Publications: Park Ridge, NJ, USA, 1988; Chapter 15; pp. 303-329. 
106. Perthuis, H.; Colomban, P. $\mathrm{Li}^{+}$Eucriptite Superionic Thick Films. J. Mater. Sci. Lett. 1985, 4, $344-346$. [CrossRef]

107. Bruneton, E.; Bigaré, J.; Michel, D.; Colomban, P. Heterogeneity, nucleation, shrinkage and bloating in sol-gel glass ceramics. The case of LAS compositions. J. Mater Sci. 1997, 32, 3541-3548. [CrossRef]

108. Colomban, P.; Lapous, N. New sol-gel matrices of chemically stable composites BAS, NAS and CAS. Compos. Sci. Technol. 1996, 56, 737-746. [CrossRef]

109. Nagata, K.; Furuno, M. Properties of electrooptic $(\mathrm{Pb}, \mathrm{La})(\mathrm{Zr}, \mathrm{Ti}) \mathrm{O}_{3}$ ceramics fabricated by partial Coprecipitation methods. Jpn. J. Appl. Phys. 1992, 31, 3201-3204. [CrossRef]

110. Vendange, V.; Colomban, P. Elaboration and thermal stability of alumina, alumino-silicate. Fe, Co, Ni magnetic nanocomposites prepared through a sol-gel route. Mater. Sci. Eng. A 1993, 168, 199-203. [CrossRef]

111. Vendange, V.; Flavin, E.; Colomban, P. Gyromagnetic microwave resonance of cobalt-aluminoborosilicate nanocomposites. J. Mater. Sci. Lett. 1996, 15, 137-141. [CrossRef]

112. Mouchon, E.; Colomban, P. Microwave absorbent: Preparation, mechanical properties and RF/microwave conductivity of SiC (and/or mullite) fibres reinforced NASICON matrix composites. J. Mater. Sci. 1996, 31, 323-334. [CrossRef]

113. Karlin, S.; Colomban, P. Raman study of the chemical and thermal degradation of as received and sol-gel embedded Nicalon and Hi-Nicalon SiC fibres used in ceramic matrix composites. J. Raman Spectrosc. 1997, 28, 219-228. [CrossRef]

114. Colomban, P.; Wey, M. Sol-gel control of the matrix net-shape sintering in 3D reinforced ceramic matrix composites. J. Eur. Ceram. Soc. 1997, 17, 1475-1483. [CrossRef]

115. MacDiarmid, A.G. Silanes and their derivatives. Adv. Inorg. Chem. 1961, 3, 207-256.

116. Tanaka, H.; Kurachi, Y. Synthesis of beta-SiC powder from organic precursor and its sinterability. Ceram. Int. 1988, 14, 109-115. [CrossRef]

117. Okamura, K.; Matsuzawa, T.; Hasegawa, Y. Gamma-ray irradiation curing on polycarbosilane fibers as the precursor of SiC fibers. J. Mater. Sci. 1985, 4, 55-57.

118. Colomban, P. SiC, from Amorphous to Nanosized Materials, the Example of SiC Fibres issued of Polymer Precursors. In Silicon Carbide-Materials, Processing and Applications in Electronic Devices; Mukherjee, M., Ed.; INTECHOPEN: London, UK, 2011; Chapter 7; pp. 161-186. Available online: https:// www.intechopen.com/books/silicon-carbide-materials-processing-and-applications-in-electronic-devices/ sic-from-amorphous-to-nanosized-materials-the-exemple-of-sic-fibres-issued-of-polymer-precursors (accessed on 13 August 2020).

119. Durham, S.J.P.; Shanker, K.; Drew, R.A.L. Carbothermal synthesis of silicon-nitride. Effect of reaction conditions. J. Am. Ceram. Soc. 1991, 74, 31-37. [CrossRef]

120. Kroke, E.; Li, Y.L.; Lecomte, E.; Fasel, C.; Riedel, R. Silazane derived ceramics and related materials. Mater. Sci. Eng. R Rep. 2000, 26, 97-199. [CrossRef]

121. Cooke, T.F. Inorganic Fibers-A Literature review. J. Am. Ceram. Soc. 1991, 74, 2959-2978. [CrossRef]

122. Bill, J.; Kamphowe, T.W.; Muller, A.; Wichmann, T.; Zern, A.; Jalowieki, A.; Mayer, J.; Weinmann, M.; Schuhmacher, J.; Muller, K.; et al. Precursor-derived Si-(B-)C-N ceramics: Thermolysis, amorphous state and crystallization. Appl. Organomet. Chem. 2001, 15, 777-793. [CrossRef]

123. Onbattuvelli, V.; Atre, S. Review of Net Shape Fabrication of thermally Conducting Ceramics. Mater. Manuf. Process 2011, 26, 832-845. [CrossRef]

124. Corriu, R.J.P. Ceramics and nanostructures from molecular precursors. Angew. Chem. Int. Ed. 2000, 39, 1376-1398. [CrossRef]

125. Gülgun, M.A.; Nguyen, M.H.; Kriven, W.M. Polymerized Organic-Inorganic Synthesis of Mixed Oxides. J. Am. Ceram. Soc. 1999, 82, 556-560. [CrossRef]

126. Lee, S.-J.; Kriven, W.M. Crystallization and Densification of Nano-Size Amorphous Cordierite Powder Prepared by a PVA Solution-Polymerization Route. J. Am. Ceram. Soc. 1998, 81, 2605-2612. [CrossRef]

127. Lee, S.J.; Biegalski, M.D.; Kriven, W.M. Powder synthesis of barium titanate and barium orthotitanate via an ethylene glycol complex polymerization route. J. Mater. Sci. 1999, 14, 3001-3006. [CrossRef]

128. Hasegawa, Y.; Iimura, M.; Yjima, S. Synthesis of continuous Silicon-Carbide fiber. 2. Conversion of Polycarbosilane fiber into Silicon-Carbide fibers. J. Mater. Sci. 1980, 15, 720-728. [CrossRef]

129. Burns, G.T.; Taylor, R.B.; Xu, Y.R.; Zangvil, A.; Zank, G.A. High-Temperature Chemistry of the Conversion of Siloxanes to Silicon-Carbide. Chem. Mater. 1992, 4, 1313-1323. [CrossRef] 
130. Bayya, S.S.; Villaloos, G.R.; Hunt, M.P.; Sanghera, J.S.; Sadowski, B.M.; Aggarwal, I.D.; Cinibulk, M.; Carney, C.; Keller, K. Development of transparent polycrystalline Beta-Silicon Carbide. In Material Technologies and Applications to Optics, Structures, Components, and Sub-Systems; Robichaud, J.L., Krodel, M., Goodman, W.A., Eds.; SPIE: Bellingham, MA, USA, 2013; Volume 8837, p. UNSP 88370S. [CrossRef]

131. Suzuki, T.; Kosacki, I.; Colomban, P.; Anderson, H. Electrical Conductivity and Lattice Defects in Nanocrystalline $\mathrm{CeO}_{2}$ thin films. J. Am. Ceram. Soc. 2001, 84, 2007-2014. [CrossRef]

132. Kosacki, I.; Petrovsky, V.; Anderson, H.; Colomban, P. Raman Spectroscopy of Nanocrystalline Ceria and Zirconia Thin Films. J. Am. Ceram. Soc. 2002, 85, 2646-2650. [CrossRef]

133. Naslain, R. Design, preparation and properties of non-oxide CMCs for application in engines and nuclear reactors: An overview. Compos. Sci. Technol. 2004, 64, 155-170. [CrossRef]

134. Parcianello, G.; Bernardo, E.; Colombo, P. Mullite/Zirconia Nanocomposites from a Preceramic Polymer and Nanosized Fillers. J. Am. Ceram. Soc. 2011, 94, 1357-1362. [CrossRef]

135. Parcianello, G.; Bernardo, E.; Colombo, P. Low temperature synthesis of zircon from silicone resins and oxide nano-sized particles. J. Eur. Ceram. Soc. 2012, 32, 2819-2824. [CrossRef]

136. Shin, D.W.; Tanaka, H. Low-temperature Processing of Ceramic Wowen Fabric Ceramic-Matrix Composites. J. Am. Ceram. Soc. 1994, 77, 97-104. [CrossRef]

137. Havel, M.; Colomban, P. Rayleigh and Raman Image of the Bulk/Surface Surface Nanostructure of SiC based Fibres. Compos. Part B Eng. 2004, 35, 139-147. [CrossRef]

138. Havel, M.; Baron, D.; Colomban, P. Smart Raman/Rayleigh Imaging of Nanosized SiC Materials Using the Spatial Correlation Model. J. Mater. Sci. 2004, 39, 6183-6190. [CrossRef]

139. Havel, M.; Baron, D.; Mazerolles, L.; Colomban, P. Phonon confinment in SiC nanocrystal. Comparison of the size determination using TEM and Raman spectroscopy. Appl. Spectrosc. 2007, 61, 855-859. [CrossRef] [PubMed]

140. Yu, J.L.; Yang, J.L.; Huang, Y. The transformation mechanism from suspension to green body and the development of colloidal forming. Ceram. Int. 2011, 37, 1435-1451. [CrossRef]

141. Chaim, R.; Levin, M.; Shlayer, A.; Estournes, C. Sintering and densification of nanocrystalline ceramic oxide powders: A review 2. Adv. Appl. Ceram. 2008, 107, 159-169. [CrossRef]

142. Gao, L.; Li, W.; Wang, H.Z.; Zhou, J.X.; Chao, Z.J.; Zai, Q.Z. Fabrication of nano Y-TZP materials by superhigh pressure compaction. J. Eur. Ceram. Soc. 2001, 21, 135-138. [CrossRef]

143. Henderson, R.J.; Chandler, H.W.; Akisanya, A.R.; Barber, H.; Moriarty, B. Finite element modeling of cold isostatic pressing. J. Eur. Ceram. Soc. 2000, 20, 1121-1128. [CrossRef]

144. Guillon, O.; Roedel, J.; Bordia, R.K. Effect of green-state processing on the sintering stress and viscosity of alumina compacts. J. Am. Ceram. Soc. 2007, 90, 1637-1640. [CrossRef]

145. Ananthakumar, S.; Manohar, P.; Warrier, K.G.K. Effect of boehnite and organic binders on extrusion of alumina. Ceram. Int. 2004, 30, 837-842. [CrossRef]

146. Nampi, P.P.; Kume, S.; Hotta, Y.; Watari, K.; Ito, M.; Toda, H.; Matsutani, A. The effect of polyvinyl alcohol as a binder and stearic acid as an internal lubricant in the formation, and subsequent sintering of spray-dried alumina. Ceram. Int. 2011, 37, 3445-3450. [CrossRef]

147. Lagrange, J.L.; Colomban, P. Double particle reinforcement of Ceramic-matrix composites prepared by a Sol-Gel route. Compos. Sci. Technol. 1998, 58, 653-658. [CrossRef]

148. Colomban, P. Sol-gel route to functional and hierarchical ceramic matrix composites. In Proceedings of the 3rd International Conference on Intelligent Materials and 3rd European Conference on Smart Structures and Materials ICIM'96, ECSSM'96, Lyon'96, Lyon, France, 3-5 June 1996; Gobin, P.F., Tatibouet, J., Eds.; SPIE: Bellingham, MA, USA, 1996; Volume 2779, pp. 813-818.

149. Xue, J.X.; Liu, J.X.; Xie, B.H.; Zhang, G.J. Pressure-induced preferential grain growth, texture development and anisotropic properties of hot pressed hexagonal boron nitride ceramics. Scr. Mater. 2011, 65, 966-969. [CrossRef]

150. Shui, A.; Zhang, Y.; Uchida, N.; Uematsu, K. Origin of shape deformation during sintering of alumina compacts. J. Ceram. Soc. Jpn. 1998, 106, 873-876. [CrossRef]

151. Chantaramee, N.; Tanaka, S.; Kato, Z.; Uchida, N.; Uematsu, K. Characterization of particles packing in alumina green tape. J. Eur. Ceram. Soc. 2009, 29, 943-948. [CrossRef]

152. Imran, Z.M.; Tanaka, S.; Uematsu, K. Effect of polyacrilic acid (PAA) binder system on particle orientation during dry-pressing. Powder Technol. 2009, 196, 133-138. [CrossRef] 
153. Mandal, H. New developments in alpha-SiAlON ceramics. J. Eur. Ceram. Soc. 1999, 19, 2349-2357. [CrossRef]

154. Chai, Q.Z.; Yang, D.; Zhao, X.M.; Chao, X.L.; Yang, Z.P. Lead-free (K,Na) $\mathrm{NbO}_{3}$-based ceramics with high optical transparency and large energy storage. J. Eur. Ceram. Soc. 2018, 101, 2321-2329. [CrossRef]

155. Ikesue, A. Ce:YAG ceramic scintillator for electron beam detector. J. Ceram. Soc. Jpn. 2000, 108, 1020-1023. [CrossRef]

156. Cho, J.; Miyazawa, K.; Kuwabara, M. Low temperature synthesis of $\mathrm{BaTiO}_{3}$ ceramics by sol-gel process and its electro-optic properties. In Key Engineering Materials; Murata, M., Koumoto, K., Takenatka, T., Fujitsu, S., Eds.; Trans Tech Publication: Bäch, Switzerland, 2002; Volume 214-215, pp. 43-48.

157. Carty, W.M.; Senapatti, U. Porcelain-raw materials, processing, phase evolution, and mechanical behaviour. J. Am. Ceram. Soc. 1998, 81, 3-20. [CrossRef]

158. Sciau, P.; Noé, L.; Colomban, P. Metal nanoparticles in contemporary potters' master pieces: Lustre and red "pigeon blood" pottery: Models to understand the ancient technology. Ceram. Int. 2016, 42, 15349-15357. [CrossRef]

159. Matsubara, M.; Yamaguchi, T.; Kikuta, K.; Hirano, S. Sinterability and piezoelectric properties of $(\mathrm{K}, \mathrm{Na}) \mathrm{NbO}_{3}$ ceramics with novel sintering aid. Jpn. J. Appl. Phys. 2004, 43, 7159-7163. [CrossRef]

160. Nicholas, J.D.; De Jonghe, L.C. Prediction and evaluation of sintering aids for Cerium Gadolinium Oxide. Solid State Ionics 2007, 178, 1187-1194. [CrossRef]

161. Kleebe, H.J.; Hoffmann, M.J.; Ruhle, M. Influence of secondary phase chemistry on grain-boundary film thickness in silicon-nitride. Zeitschr. Metallkunde 1992, 83, 610-617.

162. Cheng, H.F.; Lin, T.F.; Hu, C.T.; Lin, I.N. Effect os sintering aids on microstructures and PTCR characteristics of $\left(\mathrm{Sr}_{0.2} \mathrm{Ba}_{0.8}\right) \mathrm{TiO}_{3}$ ceramics. J. Am. Ceram. Soc. 1993, 76, 827-832. [CrossRef]

163. Radford, K.C.; Bratton, R.J. Zirconia Electrolyte Cells. 1. Sintering studies. J. Mater. Sci. 1979, 14, 59-65. [CrossRef]

164. Gomez, E.; Echeberria, J.; Iturriza, I.; Castro, F. Liquid phase sintering of $\mathrm{SiC}$ with additions of $\mathrm{Y}_{2} \mathrm{O}_{3}, \mathrm{Al}_{2} \mathrm{O}_{3}$ and $\mathrm{SiO}_{2}$. J. Eur. Ceram. Soc. 2004, 24, 2895-2903. [CrossRef]

165. Greskovich, C.; Prochazka, S. Stability of $\mathrm{Si}_{3} \mathrm{~N}_{4}$ and liquid phase(s) sintering. J. Am. Ceram. Soc. 1981, 64, C96-C97. [CrossRef]

166. Huang, C.L.; Weng, M.H.; Lion, C.T.; Wu, C.C. Low temperature sintering and microwave dielectric properties of $\mathrm{Ba}_{2} \mathrm{Ti}_{9} \mathrm{O}_{20}$ ceramics using glass additions. Mater. Res. Bull. 2000, 35, 2445-2456. [CrossRef]

167. Tong, J.H.; Clark, D.; Bernau, L.; Subramaniyan, A.; O’Hayre, R. Proton-conducting yttrium-doped barium cerate ceramics synthesized by a cos-effective solid-state reactive sintering method. Solid State Ionics 2010, 181, 1486-1498. [CrossRef]

168. Slodczyk, A.; Lacroix, O.; Colomban, P. Water Pressure Enhanced Sintering of Alkaline-Earth Perovskite ceramics. Ceram. Int. 2015, 41, 11528-11533. [CrossRef]

169. Yoo, J.Y.; Lee, C.; Jeong, Y.H.; Chung, K.H.; Lee, D.; Paik, D. Microstructural and piezoelectric properties of low temperature sintering PMN-PZT ceramics with the amount of $\mathrm{Li}_{2} \mathrm{CO}_{3}$ addition. Mater. Chem. Phys. 2005, 90, 386-390. [CrossRef]

170. Mori, M.; Hiei, Y.; Sammes, N.M. Sintering behaviour and mechanism of Sr-doped lanthanum chromites with A site excess composition in air. Solid State Ionics 1999, 123, 103-111. [CrossRef]

171. Gil, V.; Tartaj, J.; Moure, C.; Duran, P. Sintering, microstructural development, and electrical properties of gadolinia-doped ceria electrolyte with bismuth oxide as a sintering aid. J. Eur. Ceram. Soc. 2006, 26, 3161-3171. [CrossRef]

172. Yao, K.; He, X.J.; Xu, Y.; Chen, M.M. Screen-printed piezoelectric ceramic thick films with sintering additives introduced through a liquid-phase approach. Sens. Actuators A Phys. 2005, 118, 342-348. [CrossRef]

173. Pollet, M.; Marinel, S. Low temperature sintering of $\mathrm{CaZrO}_{3}$ using lithium fluoride addition. J. Eur. Ceram. Soc. 2003, 23, 1925-1933. [CrossRef]

174. Stevenson, A.J.; Kupp, E.R.; Messing, G.L. Low temperature, transient liquid phase sintering of $\mathrm{B}_{2} \mathrm{O}_{3}-\mathrm{SiO}_{2}$-doped Nd:YAG transparent ceramics. J. Mater. Sci. 2011, 26, 1151-1158. [CrossRef]

175. Riedel, R.; Passing, G.; Schonfelder, H.; Brook, R.J. Synthesis of dense silicon-based ceramics at low-temperatures. Nature 1992, 355, 714-717. [CrossRef]

176. Zhang, S.C.; Hilmas, G.E.; Fahrenholtz, W.G. Pressureless densification of zirconium diboride with boron carbide addition. J. Am. Ceram. Soc. 2006, 89, 1544-1550. [CrossRef]

177. Presser, V.; Nickel, K.G. Silica on silicon carbide. Crit. Rev. Solid State Mater. Sci. 2008, 33, 1-99. [CrossRef] 
178. Grande, T.; Sommerset, H.; Hagen, E.; Wiik, K.; Einarsrud, M.A. Effect of weight loss on liquid-phase-sintered silicon carbide. J. Am. Ceram. Soc. 1997, 80, 1047-1052. [CrossRef]

179. Negita, K. Effective sintering aids for silicon-carbide ceramics-Reactivities of Silicon Carbide with various additives. J. Am. Ceram. Soc. 1986, 69, C308-C310. [CrossRef]

180. Colomban, P.; Gouadec, G. The ideal ceramic fiber/oxide matrix composite: How to conciliate antagonist physical and chemical requirements? Ann. Chim. Sci. Matér. 2005, 30, 673-688. [CrossRef]

181. Colomban, P. Proton and Protonic Species: The Hidden Face of Solid State Chemistry. How to Measure H-Content in Materials? Fuel Cells 2013, 13, 6-18. [CrossRef]

182. Slodczyk, A.; Colomban, P. Probing the Nanodomain Origin and Phase Transition Mechanisms in (un)poled PMN-PT single Crystals and textured Ceramics. Materials 2010, 3, 5007-5029. [CrossRef] [PubMed]

183. Goodenough, J.B. Narrow-band electrons in transition-metal oxides. Czech. J. Phys. B 1967, 17, $304-336$. [CrossRef]

184. Goodenough, J.B. Metallic oxides. Progr. Solid State Chem. 1971, 5, 145-399. [CrossRef]

185. Goodenough, J.B.; Zhou, J.-S. Localized to Itinerant Electronic Transitions in Transition-Metal Oxides with the Perovskite Structure. Chem. Mater. 1998, 10, 2980-2993. [CrossRef]

186. Rao, C.N.R. Structural aspects of superconducting cuprates. Acta Crystallog. B Structur. Sci. 1995, 51, 604-618. [CrossRef]

187. Ganguly, P.; Rao, C.N.R. Electron transport properties of transition metal oxide systems with the $\mathrm{K}_{2} \mathrm{NiF}_{4}$ structure. Mater. Res. Bull. 1973, 8, 405-412. [CrossRef]

188. Arul, N.S.; Nithya, V.D. Revolution of Perovskite: Synthesis, Properties and Applications; Springer Nature: Singapore, 2020.

189. Haghenmuller, P.; Van Gool, W. (Eds.) Solid Electrolytes. General Principles, Characterization, Materials Applications, 1st ed.; Academic Press: New York, NY, USA, 1978.

190. Mahan, G.D.; Roth, W.L. Superionic Conductors; Springer: Boston, MA, USA, 1976.

191. Boilot, J.-P.; Collin, G.; Colomban, P.; Comes, R. X-ray-scattering study of the fact-ion conductor beta"-alumina. Phys. Rev. B 1980, 22, 5912-5923. [CrossRef]

192. Colomban, P.; Lucazeau, G. Vibrational study and conduction mechanismes in beta-alumina. I. Stoichiometric beta alumina. J. Chem. Phys. 1980, 72, 1213-1224. [CrossRef]

193. Collongues, R.; Gourier, D.; Kahn, A.; Boilot, J.-P.; Colomban, P.; Wicker, A. $\beta$ Alumina, a Typical Solid Electrolyte: Latest Developments in Fundamental Approach and in Battery Utilization. J. Phys. Chem. Solids 1984, 45, 981-1013. [CrossRef]

194. Xu, L.Q.; Li, J.Y.; Liu, C.; Zou, G.Q.; Hou, H.S.; Ji, X.B. Research progress in inorganic solid-state electrolytes for sodium-ion batteries. Acta Pysico-Chim. Sin. 2020, 36, UNSP 1905013.

195. Lenain, G.E.; McKinstry, H.A.; Limaye, S.Y.; Woodward, A. Low-thermal expansion of alkali-zirconium phosphate. Mater. Res. Bull. 1984, 19, 1451-1456. [CrossRef]

196. Limaye, S.Y.; Agrawal, D.K.; Roy, R.; Mehrotra, Y. Synthesis, sintering and thermal-expansion of $\mathrm{Ca}_{1-x} \mathrm{Sr}_{x} \mathrm{Zr}_{4} \mathrm{P}_{6} \mathrm{O}_{24}$-An ultra-low thermal-expansion ceramic system. J. Mater. Sci. 1991, 26, 93-98. [CrossRef]

197. Colomban, P.; Mouchon, E. Phase transition in thermal history and expansion of NASICON solid solution and lithium derivative ceramics and of $\mathrm{SiC}$ (mullite) fibers-NASICON composites. Solid State Ionics 1994, 73, 209-220. [CrossRef]

198. Woodcock, D.A.; Lightfoot, P.; Ritter, C. Mechanism of low thermal expansion in the cation-ordered Nasicon structure. Chem. Comm. 1998, 1, 107-108. [CrossRef]

199. Pet'kov, V.I.; Asabina, E.A. Thermophysical properties of NZP ceramics (A review). Glass Ceram. 2004, 61, 233-239. [CrossRef]

200. Blinov, V.A. Mechanism of nucleated crystallisation of glasses in lithia-alumina-silica and cordierite systems. J. Mater. Sci. 1969, 4, 461-468. [CrossRef]

201. Yang, J.S.; Sakka, S.; Yoko, T.; Kozuka, H. Preparation of lithium aluminosilicate glass-ceramic monolith from metal oxide solution. 2. Conversion of gel to glass-ceramic monoliths and their properties. J. Mater. Sci. 1991, 26, 1827-1833. [CrossRef]

202. Kikuchi, N.; Sei, T.; Tsuchiya, T.; Hayashi, S.; Hayamizu, K. Preparation of cordierite ceramics by the sol-gel process and their properties. J. Ceram. Soc. Jpn. 1993, 101, 824-829. [CrossRef] 
203. Low, I.M.; Suhermann, P.M.; Phillips, P.N. Synthesis and properties of spodumene-modified mullite ceramics formed by sol-gel processing. J. Mater. Sci. Lett. 1997, 16, 982-984. [CrossRef]

204. Khosrovani, N.; Sleight, A.W. Strong anisotropic thermal expansion in oxides. Int. J. Inorg. Mater. 1999, 1, 3-10. [CrossRef]

205. Ren, M.G.; Du, J.C. Structural origin of the thermal and diffusion behaviors of lithium aluminosilicate crystal polymorphs anf glasses. J. Am. Ceram. Soc. 2016, 99, 2823-2833. [CrossRef]

206. Ogiwara, T.; Noda, Y.; Kimura, O. Low-Temperature Sintering of beta-Spodumene Ceramics Using $\mathrm{Li}_{2} \mathrm{O}_{-}-\mathrm{GeO}_{2}$ as a Sintering Additive. J. Am. Ceram. Soc. 2013, 96, 2577-2582. [CrossRef]

207. Xu, H.W.; Heaney, P.J.; Yates, D.M.; Von Dreele, R.B.; Bourke, M.A. Structural mechanisms underlying near-zero thermal expansion in beta-eucryptite: A combined synchrotron $\mathrm{x}$-ray and neutron Rietveld analysis. J. Mater. Res. 1999, 14, 3138-3151. [CrossRef]

208. Mittal, R.; Gupta, M.K.; Chaplot, S.L. Phonons and anomalous thermal expansion behaviour in crystalline solids. Progr. Mater. Sci. 2018, 92, 360-445. [CrossRef]

209. Lichtenstein, A.I.; Jones, R.O.; de Gironcoli, S.; Baroni, S. Anisotropic thermal expansion in silicates: A density functional study of beta-eucryptite and related materials. Phys. Rev. B 2000, 62, 11487-11493. [CrossRef]

210. Colomban, P.; Courret, H.; Romain, F.; Gouadec, G.; Michel, D. Sol-gel-prepared pure and lithium-doped hexacelsian polymorphs: An infrared, Raman, and thermal expansion study of the beta-phase stabilization by frozen short-range disorder. J. Am. Ceram. Soc. 2000, 83, 2974-2982. [CrossRef]

211. Colomban, P. Orientational Disorder, Glass-Crystal Transition and Superionic Conductivity in NASICON. Solid State Ionics 1986, 21, 97-115. [CrossRef]

212. Colomban, P. Raman Study of the Polymer-Superionic NASICON Transformation. Dynamics, Static inorganic orientational Disorder and Superionic Conductivity. J. Mol. Struct. 1986, 143, 191-194. [CrossRef]

213. Collin, G.; Comes, R.; Boilot, J.-P.; Colomban, P. Disorder of tetrahedra in Nasicon-type structure-I.: $\mathrm{Na}_{3} \mathrm{Sc}_{2}\left(\mathrm{PO}_{4}\right)_{3}$ Structures and Ion-Ion correlations. J. Phys. Chem. Solids 1986, 47, 845-854. [CrossRef]

214. Heitjans, P.; Masoud, M.; Feldhoff, A.; Wilkening, M. NMR and impedance studies of nanocrystalline and amorphous ion conductors: Lithium niobate as a model system. Faraday Discuss. 2007, 134, 67-82. [CrossRef]

215. Zheng, Z.F.; Fang, H.Z.; Yang, F.; Liu, Z.K.; Wang, Y. Amorphous $\mathrm{LiLaTiO}_{3}$ as Solid Electrolyte Material. J. Electrochem. Soc. 2014, 161, A473-A479. [CrossRef]

216. Soraru, G.D.; Dallapiccola, E.; D'Andrea, G. Mechanical characterization of sol-gel-derived silicon oxycarbide glasses. J. Am. Ceram. Soc. 1996, 79, 2074-2080. [CrossRef]

217. Boulton, J.M.; Jones, K.; Emblem, H.G. Gels, Filaments and fibers from alkoxisilanes and aluminum chlorhydrate polyols complexes. J. Mater. Sci. 1989, 24, 979-990. [CrossRef]

218. Yoko, T.; Kamiya, K.; Tanaka, K. Preparation of multiple oxide $\mathrm{BaTiO}_{3}$ fibers by the Sol-Gel method. J. Mater. Sci. 1990, 25, 3922-3929. [CrossRef]

219. Tucker, D.S.; Sparks, J.S.; Esker, D.C. Production of continuous mullite fibers via Sol-Gel Processing. Am. Ceram. Bull. 1990, 69, 1971-1974.

220. Richards, E.A.; Goodbrake, C.J.; Sowman, H.G. Reactions and microstructure development in mullite fibers. J. Am. Ceram. Soc. 1991, 74, 2404-2409. [CrossRef]

221. Yuh, J.; Ninno, J.C.; Sigmund, W.A. Synthesis of barium titanate $\left(\mathrm{BaTiO}_{3}\right)$ nanofibers via electrospinning. Mater. Lett. 2005, 59, 3645-3647. [CrossRef]

222. Mouchon, E.; Colomban, P. Oxide ceramic-matrix fiber woven fabric composites exhibiting dissipative fracture behavior. Composites 1995, 26, 175-182. [CrossRef]

223. Sporn, D.; Grossmann, J.; Kaiser, A.; Jahn, R.; Berger, A. Sol-gel processing of nanostructured ceramic and ceramic/metal composite materials. Nanostructured Mater. 1995, 6, 329-332. [CrossRef]

224. Colomban, P.; Bruneton, E.; Lagrange, J.L.; Mouchon, E. Sol-gel mullite matrix-SiC and -mullite 2D woven fabric composites with or without zirconia containing interphase: Elaboration and properties. J. Eur. Ceram Soc. 1996, 16, 301-314. [CrossRef]

225. Okada, K.; Yasohama, S.; Hayashi, S.; Yasumori, A. Sol-gel synthesis of mullite long fibres from water solvent systems. J. Eur. Ceram. Soc. 1998, 18, 1879-1884. [CrossRef]

226. Son, K.C. Preparation of mullite fibers by the sol-gel method. J. Sol-Gel Sci. Technol. 1998, 13, 1017-1021.

227. Zhang, R.B.; Hou, X.B.; Ye, C.S.; Wang, B.L. Enhanced mechanical and thermal properties of anisotropic fibrous porous mullite-zirconia composites produced using sol-gel impregnation. J. Alloys Compd. 2017, 699, 511-516. [CrossRef] 
228. Vendange, V. Des membranes Micro- et Mesoporeuses aux Nanocomposites Magnetiques. Doctorate Thesis, Universté Pierre-et-Marie-Curie (Paris 6), 1994. Available online: http://www.theses.fr/1994PA066282 (accessed on 13 August 2020).

229. Colomban, P.; Vendange, V. Sol-gel routes towards magnetic nanocomposites with tailored microwave absorption. In V-Nanophase and Nanocomposite Materials II, Proceedings of the MRS Fall Meeting, Boston, MA, USA, 1-6 December 1996; Komarnemi, S., Parker, J.C., Wollenberger, H.J., Eds.; MRS: Warrendale, PA, USA, 1997; Volume 457, pp. 451-462.

230. Colomban, P. Glazes and Enamels. In Encyclopedia of Glass Science, Technology, History, and Culture, 1st ed.; Richet, P., Ed.; The Journal of the American Ceramic Society; Wiley \& Sons, Inc.: New York, NY, USA, 2020; Chapter 10.6.

231. Epler, R.A.; Epler, D.R. Glazes and Glass Coatings; The American Ceramic Society: Westerville, OH, USA, 2000.

232. Niepce, J.C.; Hugentobler, D. Capacitors. In Concise Encyclopedia of Advanced Ceramic Materials; Pergamon Press: Oxford, UK, 1991; pp. 53-57.

233. Berger, M.-H.; Bunsell, A.R. Fine Ceramic Fibers; Marcel Dekker Inc.: New York, NY, USA, 1999.

234. Bunsell, A.R. (Ed.) Handbook of Tensile Properties of Textiles and Technical Fibres, 2nd ed.; The Textile Institute, Woodhead Publishing-Elsevier: Kidlington, UK, 2018.

235. Boilot, J.-P.; Collin, G.; Colomban, P. Crystal Structure of the true NASICON: $\mathrm{Na}_{3} \mathrm{Zr}_{2} \mathrm{Si}_{2} \mathrm{PO}_{12}$. Mater. Res. Bull. 1987, 22, 669-676. [CrossRef]

236. Colomban, P. Multi-level ceramic composites: The advantage of sol-Gel routes-Composites céramiques multiniveaux ou l'intérêt des méthodes sol-gel. In Proceedings of the 8e Journées Nationales sur les Composites (JNC'8), Palaiseau, France, 16-18 Novembre 1992; Allix, O., Favre, J.P., Ladevèze, P., Eds.; AMAC: Paris, France, 1992; pp. 73-84.

237. Subasri, R.; Mathews, T.; Sreedharan, O.M.; Raghunathan, V.S. Microwave processing of sodium beta alumina. Solid State Ionics 2003, 158, 199-204. [CrossRef]

238. Subasri, R.; Nafe, H. Texture in Na-beta- $\mathrm{Al}_{2} \mathrm{O}_{3}$ due to microwave processing. Mater. Chem. Phys. 2008, 112, 16-19. [CrossRef]

239. Wang, J.; Jiang, X.P.; Wei, X.-L.; Yanh, H.; Shen, X.D. Synthesis of $\mathrm{Na}-\beta^{\prime \prime}-\mathrm{Al}_{2} \mathrm{O}_{3}$ electrolytes by microwave sintering precursors derived from the sol-gel method. J. Alloys Compd. 2010, 497, 295-299. [CrossRef]

240. Tak, S.K. Impedance study of Beta-Alumina by Microwave Sintering. AIP Conf. Proc. 2013, 1536, 1211-1212. [CrossRef]

241. Benavente, R.; Salvador, M.D.; Penaranda-Foix, F.L.; Garcia-Moreno, O.; Borrell, A. High thermal stability of microwave sintered low-epsilon( $\varepsilon$ ) beta-eucryptite materials. Ceram. Int. 2015, 41, 13817-13822. [CrossRef]

242. Colomban, P.; Mouchon, E.; Badot, J.C.; Belhadj-Tahar, N.; Fourier-Lamer, A. Radiofrequency and microwave conductivity in NASICON superionic conductor. Solid State Ionics 1992, 53-56, 813-824. [CrossRef]

243. Colomban, P.; Badot, J.-C. Frequency dependent conductivity and microwave relaxations in protonic conductors. Solid State Ionics 1993, 61, 55-62. [CrossRef]

244. Badwal, S.P.S.; Giddey, S.; Munnings, A. Kulkarni. Review of Progress in High Temperature Solid Oxide Fuel Cells. J. Aust. Ceram. Soc. 2014, 50, 23-37.

245. Colomban, P. (Ed.) Proton Conductors; Cambridge University Press: Cambridge, UK, 1992.

246. Knauth, P.; Di Vona, M.L. Solid State Proton Conductors: Properties and Applications in Fuel Cell; Wiley: New York, NY, USA, 2012.

247. Preininger, M.; Wurm, J.; Subotic, V.; Schauperl, R.; Hochenauer, C. Performance characterization of a solid oxide cell stack with chromium-based interconnects (CFY). Int. J. Hydrogen Energy 2017, 42, 28653-28664. [CrossRef]

248. Kleiminger, L.; Li, T.; Li, K.; Kelsall, G.H. Syngas $\left(\mathrm{CO}-\mathrm{H}_{2}\right)$ production using high temperature micro-tubular solid oxide electrolysers. Electrochim. Acta 2015, 179, 565-577. [CrossRef]

249. Ji, S.; Chang, I.; Lee, Y.H.; Park, J.; Lee, M.H.; Cha, S.W. Fabrication of low-temperature solid oxide fuel cells with a nanothin protective layer by atomic layer deposition. Nanoscale Res. Lett. 2013, 8, 48-53. [CrossRef]

250. Bernay, C.; Ringuede, A.; Colomban, P.; Lincot, D.; Cassir, M. Yttria-doped Zirconia Thin Films Deposited by Atomic Layer Deposition ALD—A Structural, Morphological and Electrical Characterization. J. Phys. Chem. Solids 2003, 64, 1761-1770. [CrossRef]

251. Cheong, K.Y.; Impellizzeri, G.; Fraga, M.A. Emerging Materials for Energy Conversion and Storage; Elsevier: Amsterdam, NL, USA, 2018. 
252. Zhang, J.; Jung, Y.-G. (Eds.) Advanced Ceramic and Metallic Coating and Thin Film Materials for Energy and Environmental Applications; Springer: Cham, Switzerland, 2018.

253. Schnell, J.P.; Velasco, G.; Colomban, P. Thin Films of $\beta$-Alumina-like Structure. Solid State Ionics 1981, 5 , 291-294. [CrossRef]

254. Schnell, J.P.; Velasco, G.; Croset, M.; Dubreuil, D.; Dieumegard, D.; Colomban, P. Hydrogenated Alumina-like Thin Film. Solid State Ionics 1983, 9/10, 1465-1468. [CrossRef]

255. Nenov, T.; Yordanov, S.P. Ceramic Sensors: Technology and Applications; Technomic Publishing Co. Inc.: Lancaster, PA, USA, 1996.

256. Cretin, M.; Fabry, P. Characterizations of conductive ceramics for ionic lithium potentiometric sensors. Ann. Chim. Sci. Matériaux 1995, 20, 433-438.

257. Rabinovich, L.; Gun, J.; Tsionsky, M.; Lev, O. Fuel-cell type ceramic-carbon oxygen sensors. J. Sol-Gel Sci. Technol. 1997, 8, 1077-1081. [CrossRef]

258. Rabinovich, L.; Lev, O. Sol-gel derived composite ceramic carbon electrodes. Electroanalysis 2001, 13, $265-275$. [CrossRef]

259. Sakka, S. (Ed.) Sol-gel Science and Technology; Volume 3-Applications of Sol-Gel Technology; Kluwer Academic: Hingham, MA, USA, 2003.

260. Uma, T.; Nogami, M. Development of $\mathrm{H}_{2} / \mathrm{O}_{2}$ fuel cell based on proton conducting $\mathrm{P}_{2} \mathrm{O}_{5}-\mathrm{SiO}_{2}-\mathrm{PMA}_{\mathrm{M}}$ glasses as electrolyte. In Advanced Materials Research; Nogami, M., Jin, R., Yang, W., Eds.; Trans Tech Publications: Bäch, Switzerland, 2006; Volume 11-12, pp. 149-155.

261. Yun, J.W.; Yoon, S.P.; Park, S.; Han, J.; Nam, S.W.; Lim, T.H.; Kim, J.S. Modifying the cathodes of intermediate-temperature solid oxide fuel cells with a $\mathrm{Ce}_{0.8} \mathrm{Sm}_{0.2} \mathrm{O}_{2}$ sol-gel coating. Int. J. Hydrogen Energy 2009, 34, 9213-9219. [CrossRef]

262. Yun, J.W.; Han, J.; Yoon, S.P.; Park, S.; Kim, H.S.; Nam, S.W. $\mathrm{Ce}_{0.8} \mathrm{Gd}_{0.2} \mathrm{O}_{2}$ modification on $\mathrm{La}_{0.6} \mathrm{Sr}_{0.4} \mathrm{Co}_{0.2} \mathrm{Fe}_{0.8} \mathrm{O}_{3}$ cathode for improving a cell performance in intermediate temperature solid oxide fuel cells. J. Ind. Eng. Chem. 2011, 17, 439-444. [CrossRef]

263. Choi, H.-J.; Na, Y.H.; Seo, D.W.; Woo, S.K.; Kim, S.D. Densification of gadolinia-doped ceria diffusion barriers for SOECs and IT-SOFCs by a sol-gel process. Ceram. Int. 2016, 42 Pt A, 545-550. [CrossRef]

264. Zhou, F.; Song, X.W.; Zhou, X.M.; Gao, J.Q.; Bao, J.X.; Tian, Z.; An, S.L. Limiting-current oxygen sensor with $\mathrm{LaNi}_{0.6} \mathrm{Fe}_{0.4} \mathrm{O}_{3}$-delta a dense diffusion barrier and $\mathrm{Ce}_{0.8} \mathrm{Gd}_{0.15} \mathrm{Ca}_{0.05} \mathrm{O}_{2 \text {-delta }}$ electrolyte. Ceram. Int. 2019, 45, 12060-12065. [CrossRef]

265. Park, H.K.; Smyrl, W.H.; Ward, M.D. $\mathrm{V}_{2} \mathrm{O}_{5}$ Xerogel films as intercalation host for Lithium. 1. Insertion stoichiometry, site concentration, and specific energy. J. Electrochem. Soc. 1995, 142, 1068-1073. [CrossRef] 